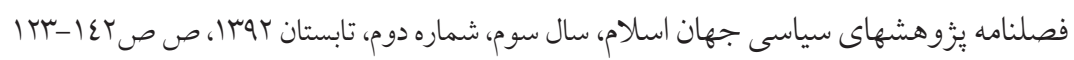

احياى هويت اسلامى و ايدئولوزى تماميتطلب آمريكايى

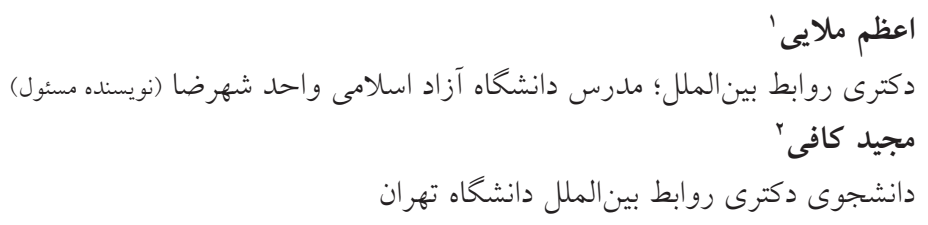

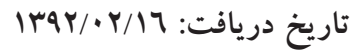

تاريخ קذيرش:

جكيده

در اين مقاله رويكرد سياست داخلى و خارجى ايالات متحده به احياى هويت اسلامى و

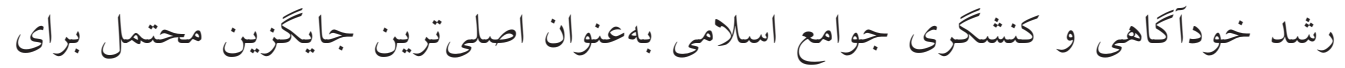

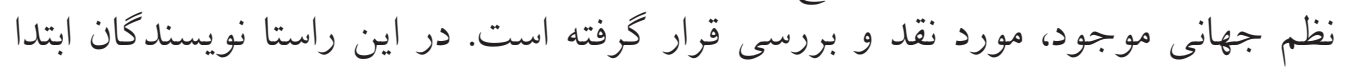

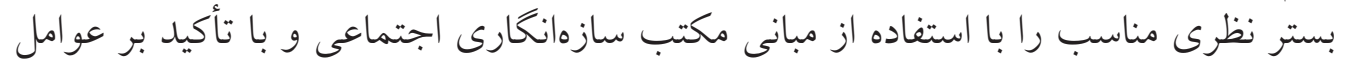

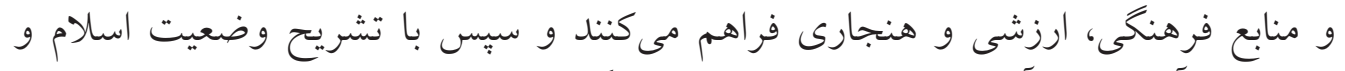

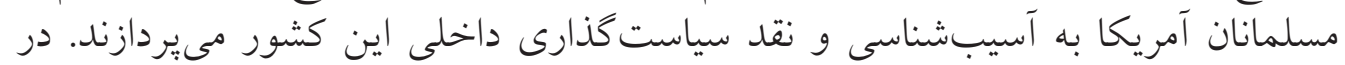

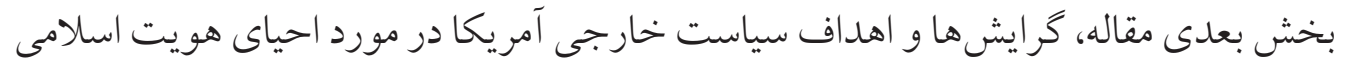

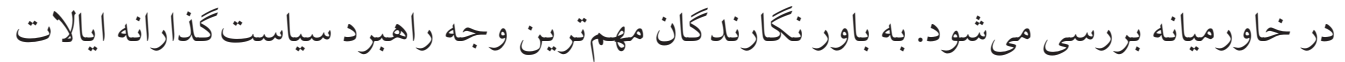

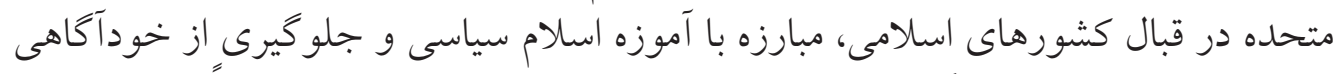

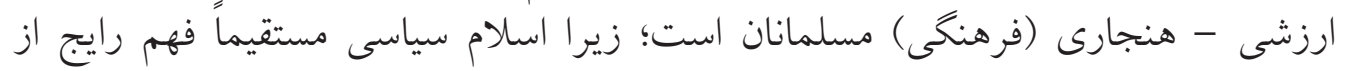

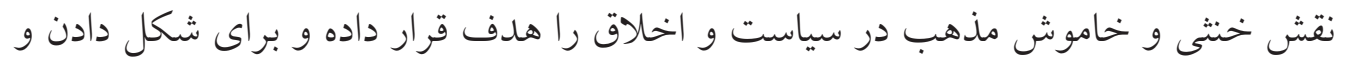

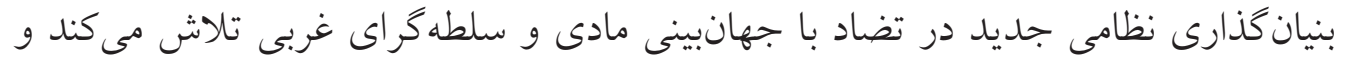

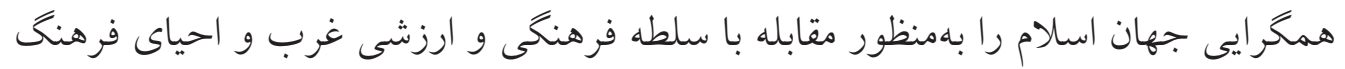

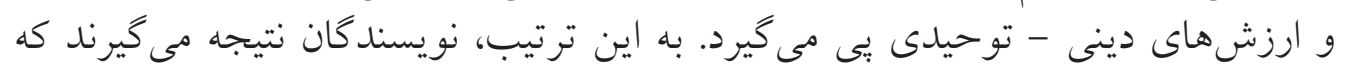

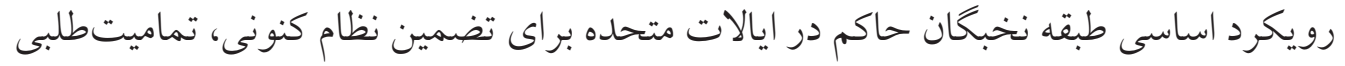

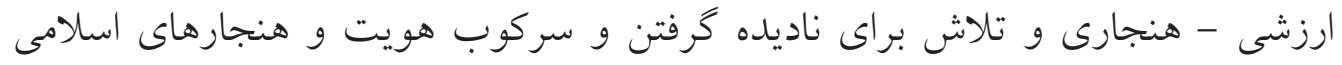

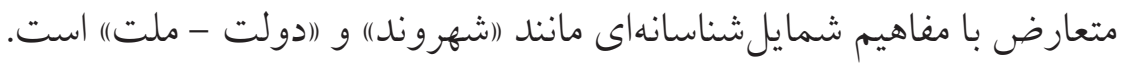

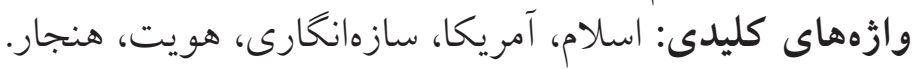

1. Azam.Molaee@gmail.com

2. Majid.Kafi@outlook.com 
رابطه ميان اسـلام و آمريكا ارتباطى جندبعدى و تاريخى اسـتـ از يكى سو، رد ياى اسلام

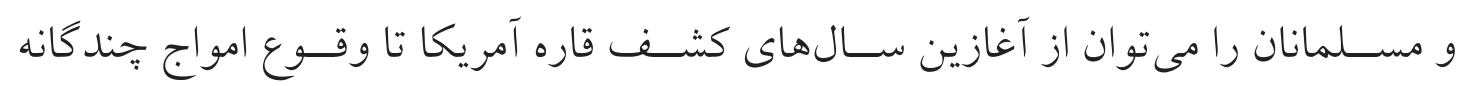
مهاجرت مســلمان به اين كشور رهخيرى كرد. از سوى ديخر، با قرار كرفتن ايالات متحداه

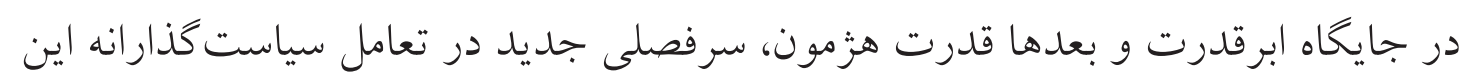

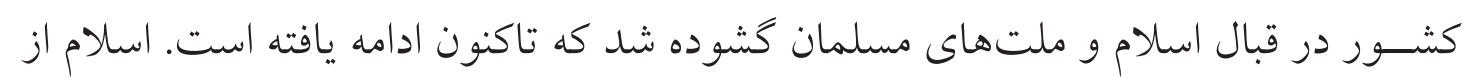

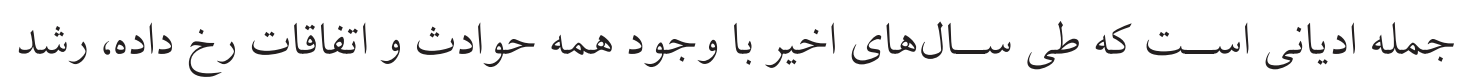

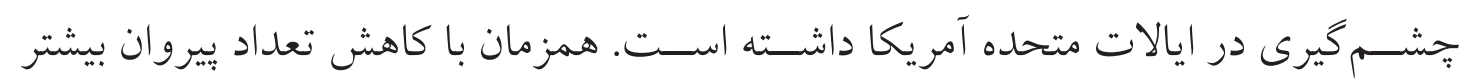

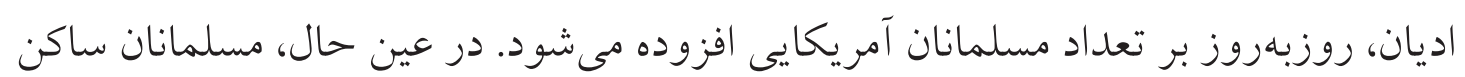

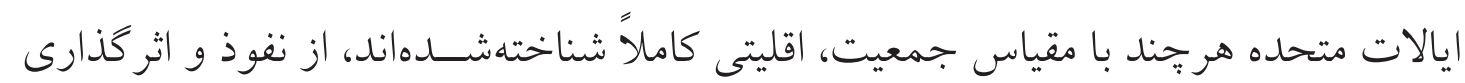

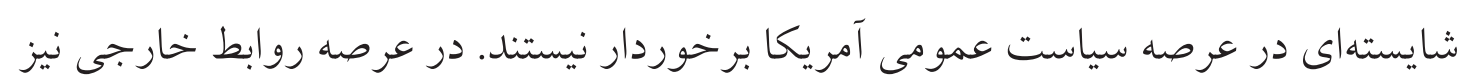

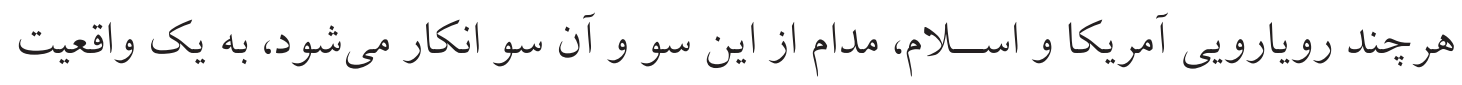

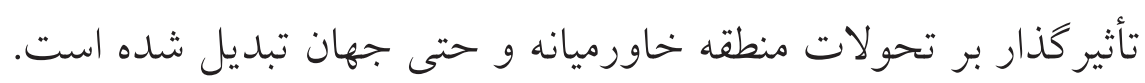

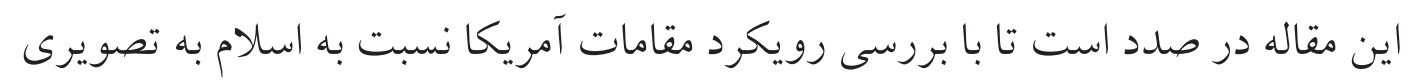

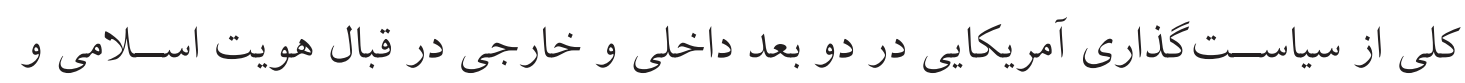

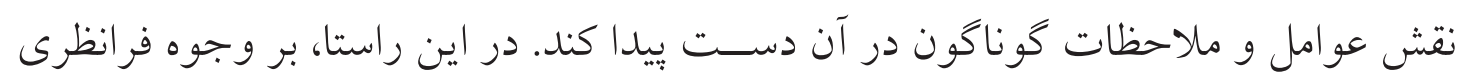

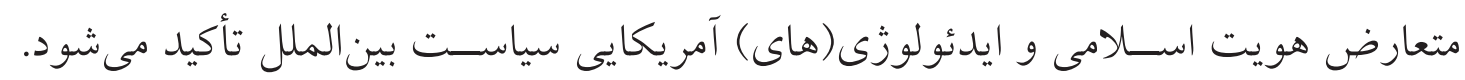

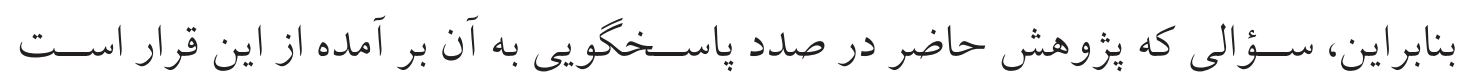

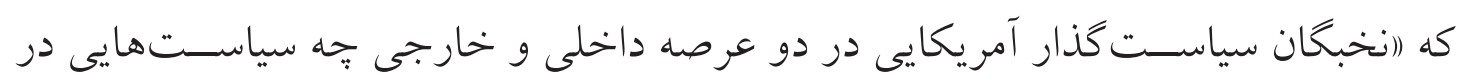

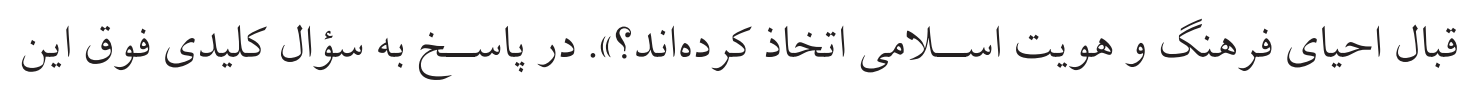

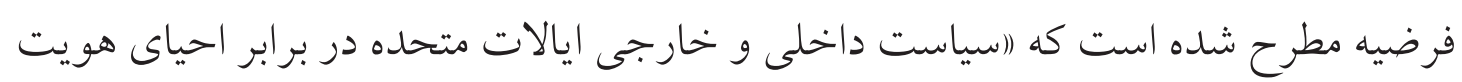

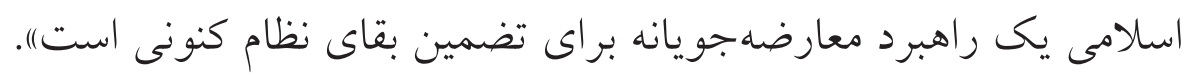

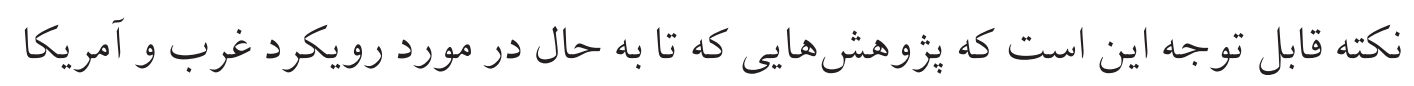

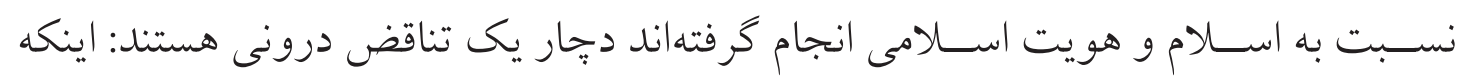

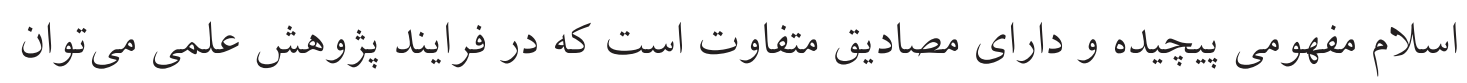

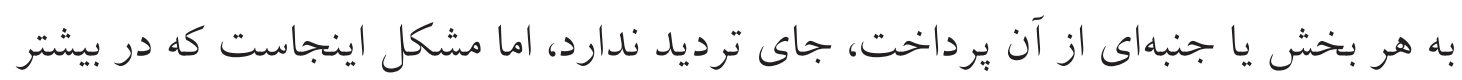

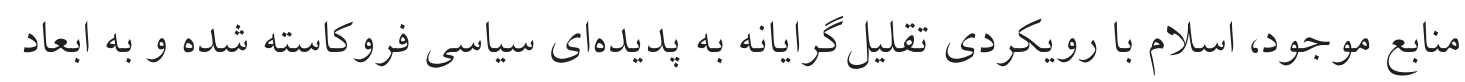


(2).

(1). فئlamic World Studies Association فصلنامه علمى - يُّوهشى

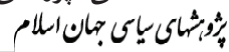

Ird

احياى هويت اسلامى و ايدئولوزى ...

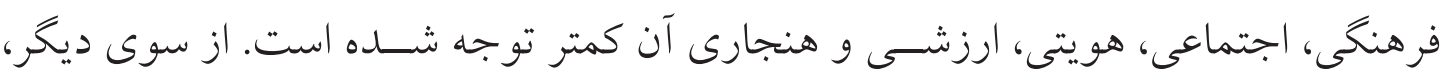

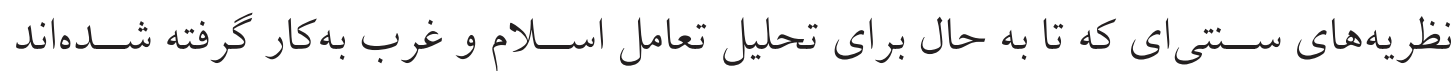

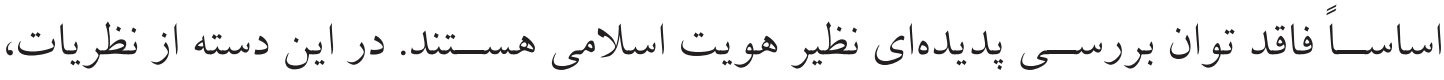

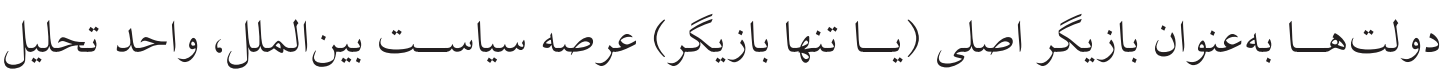

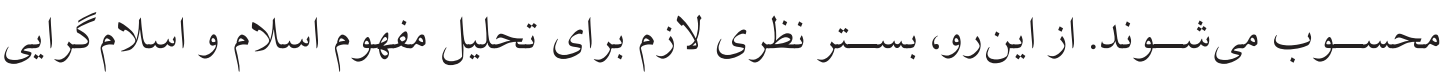

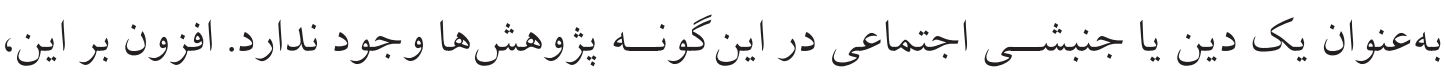

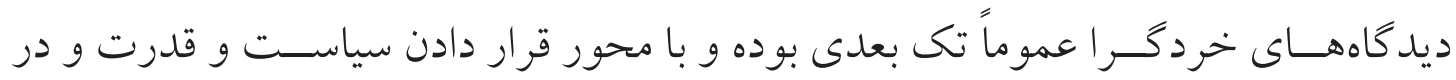

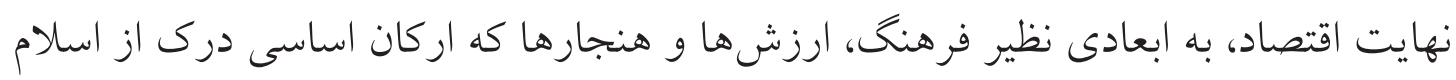
و هويت اسلامى هستند، نمى يردازند.

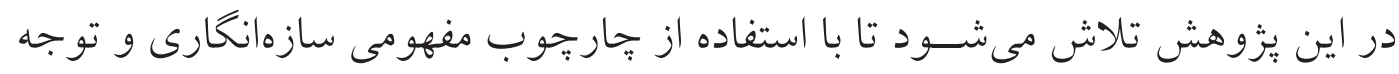

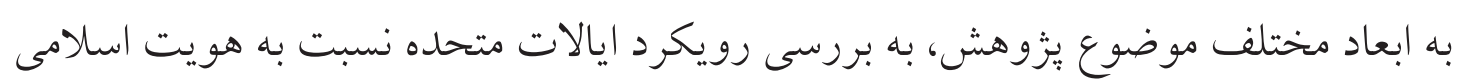

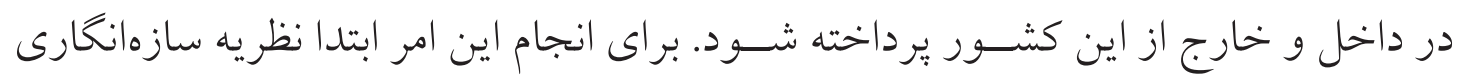

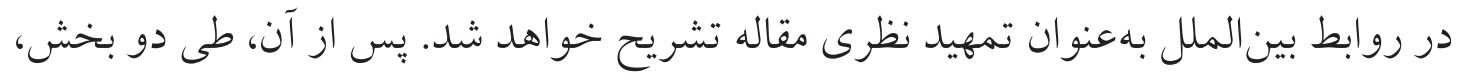

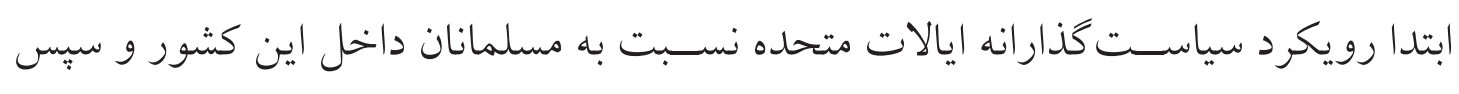

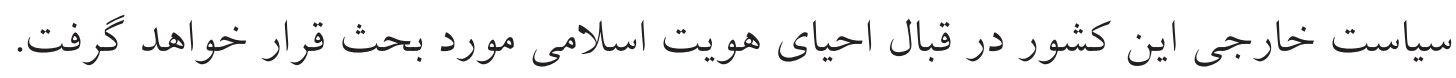

\section{تمهيد نظرى}

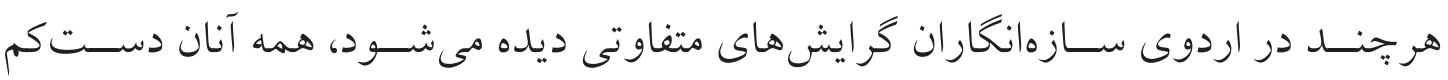

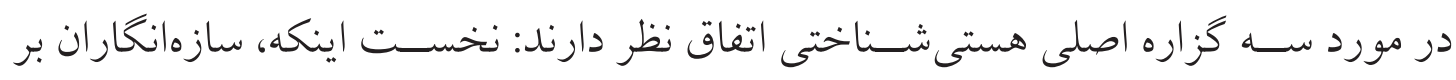

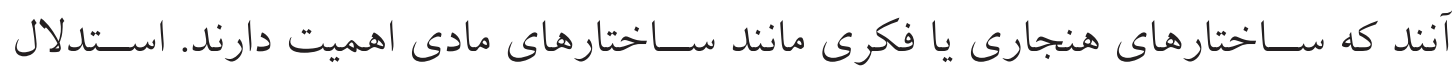

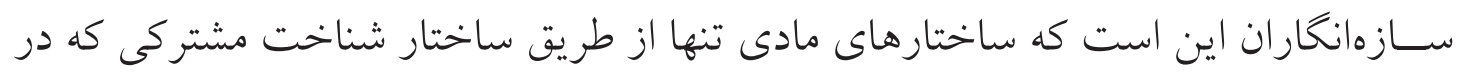

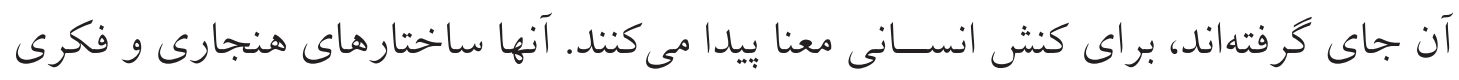

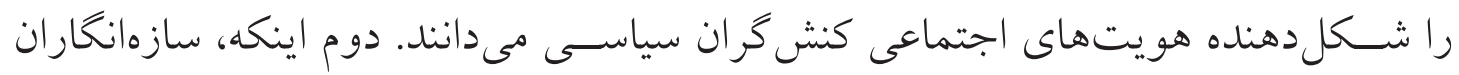

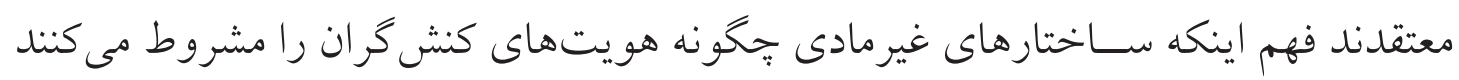

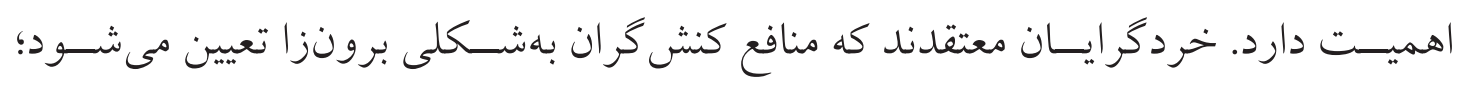

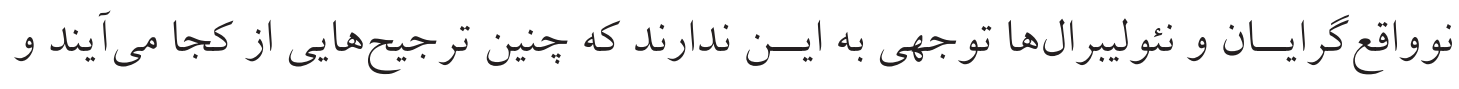

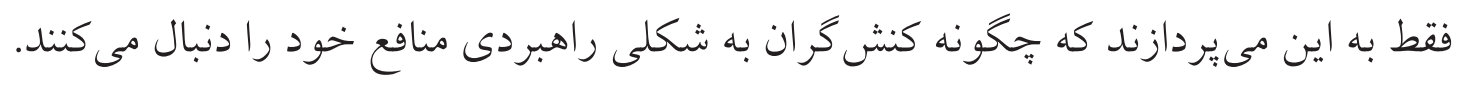


اما سازهانخاران ضمن تأكيد بر جُخونكى تبيين شكل گيرى منافع، هويتهاى اجتماعى افراد

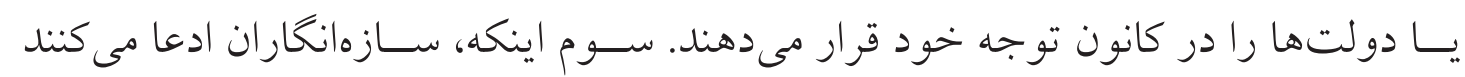

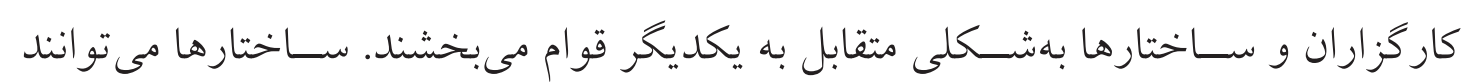

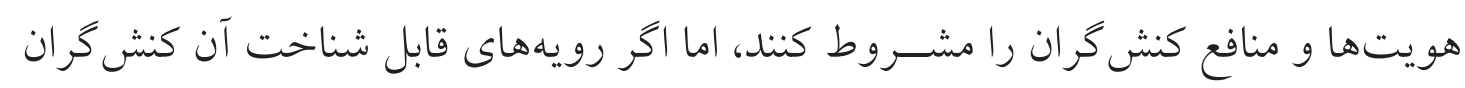

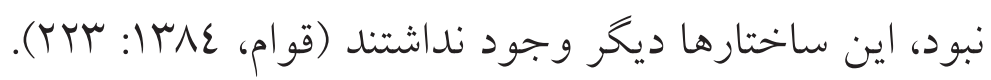

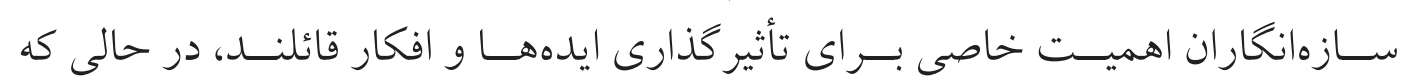

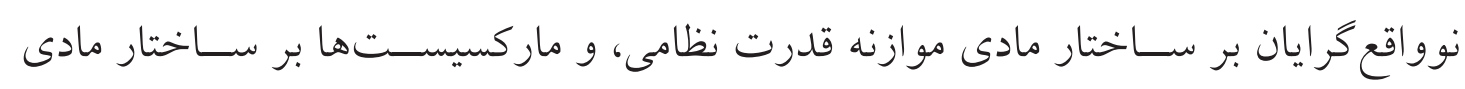

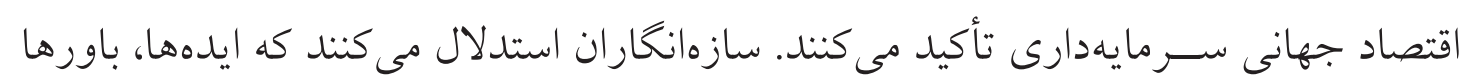

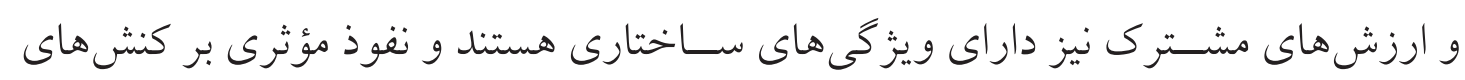

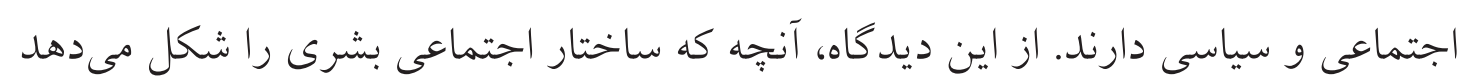

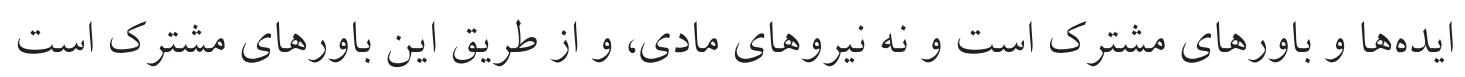

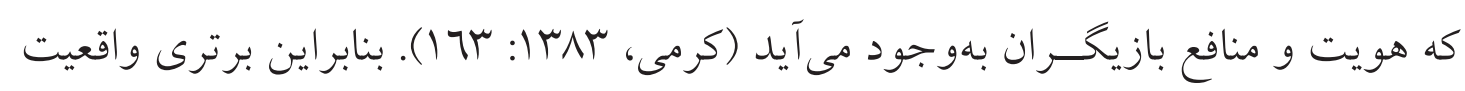

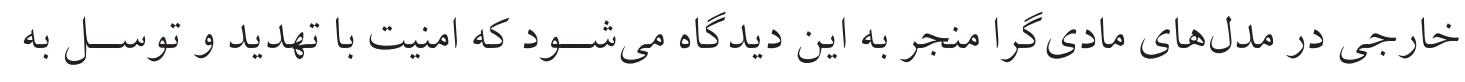

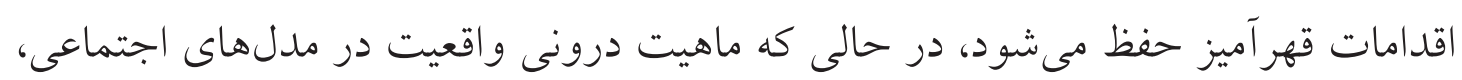

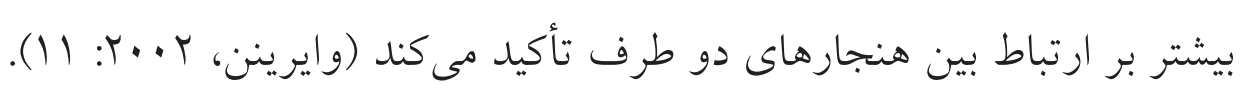

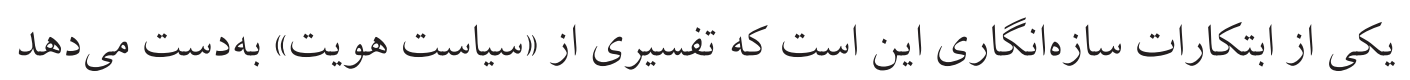

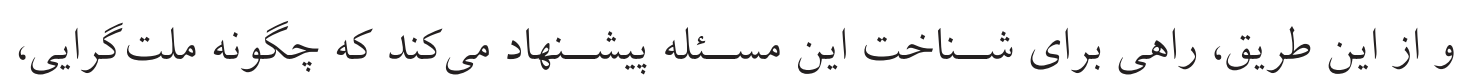

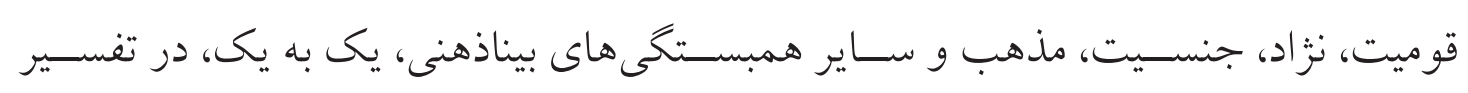

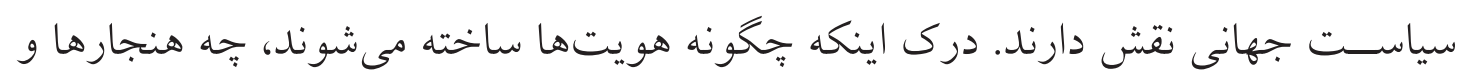

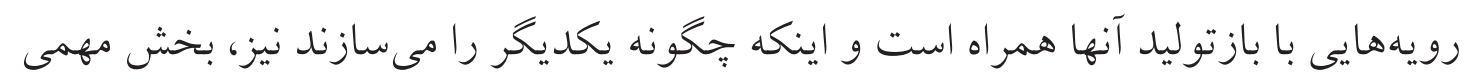

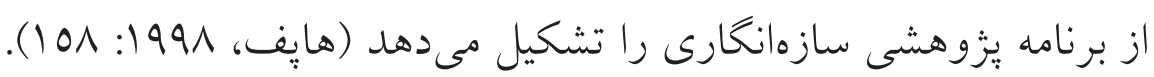

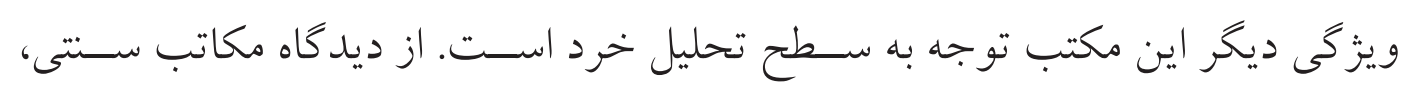

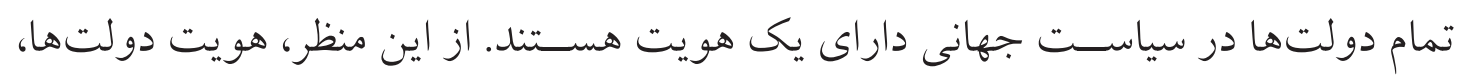

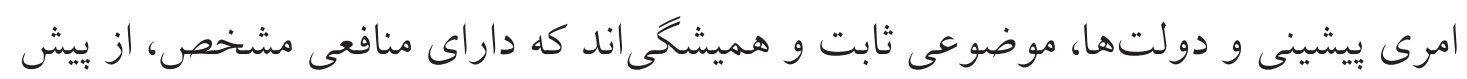

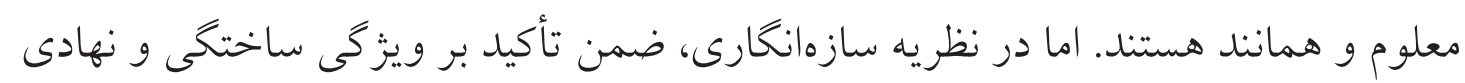

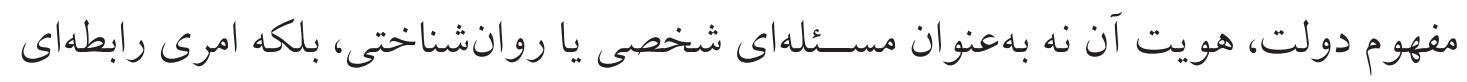

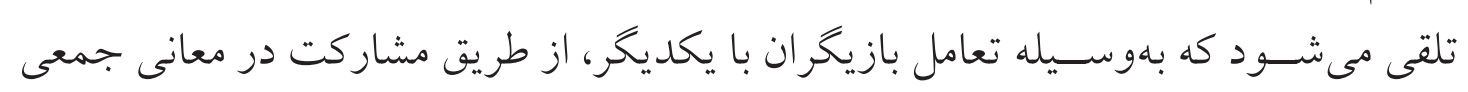




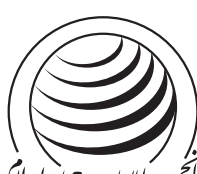

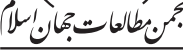
Islamic World Studies Association فصلنامه علمى - يُزوهشى

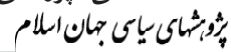

احياى هويت اسلامى و

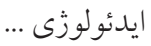

و از درون يــى دنياى اجتماعسى تكوين يافته يديد مى آيد و تغييــر مى كند (كرمى، سمبا:

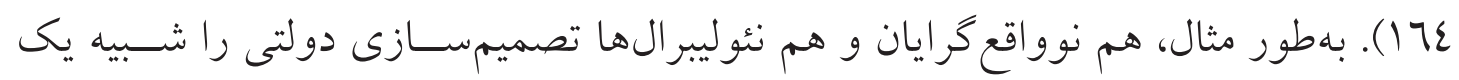

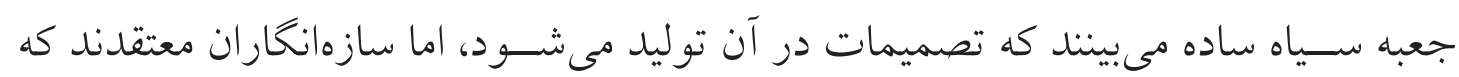

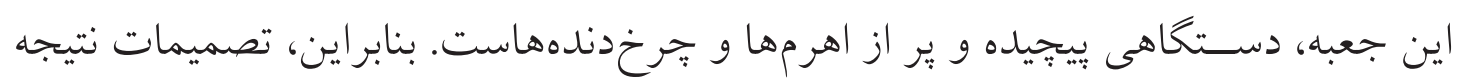

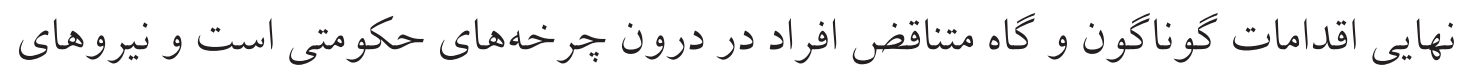

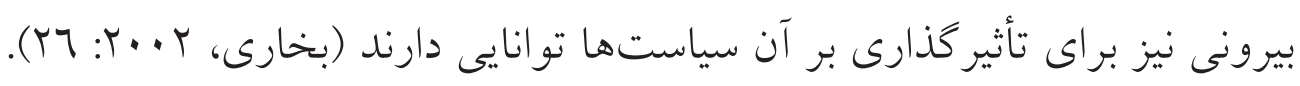

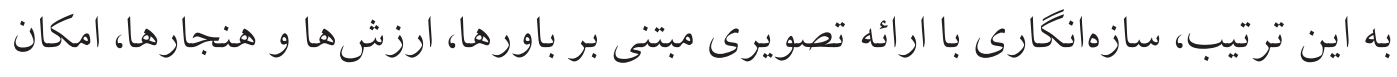

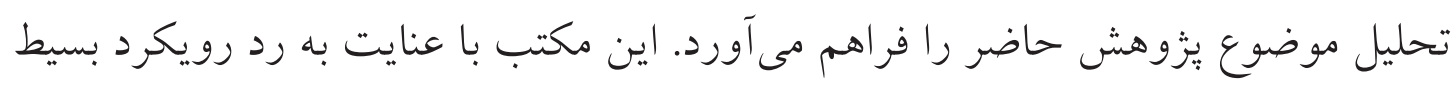

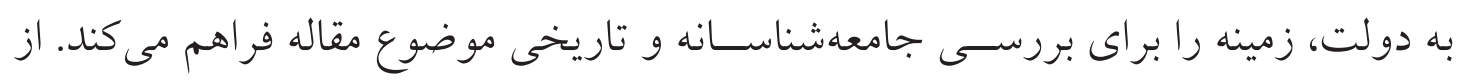

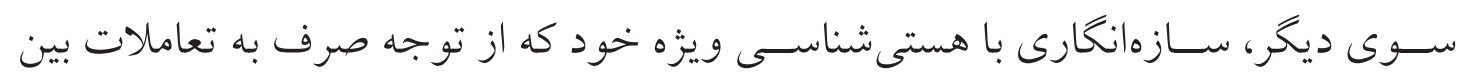

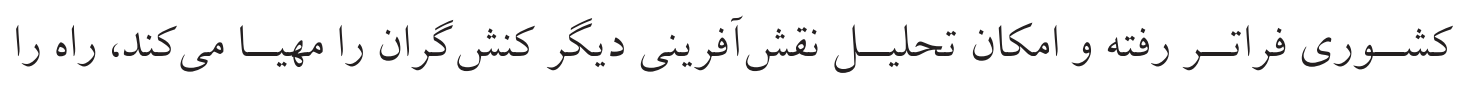

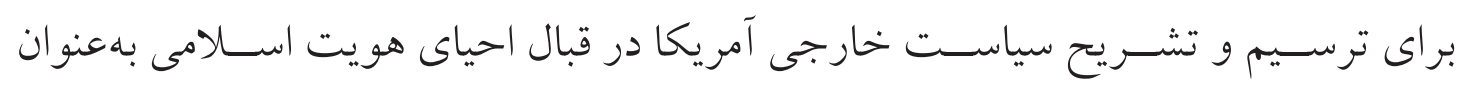

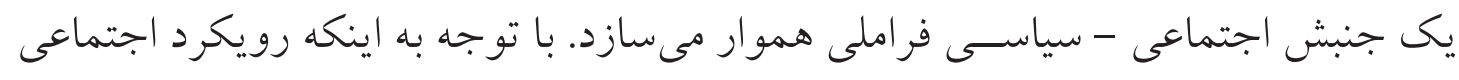

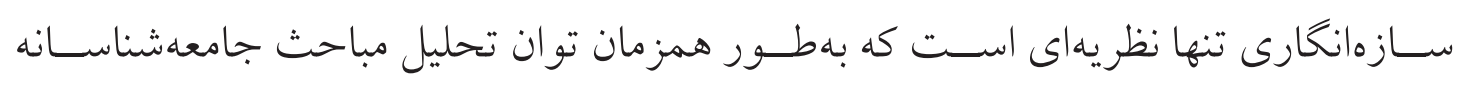

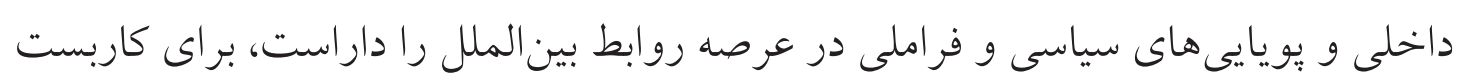

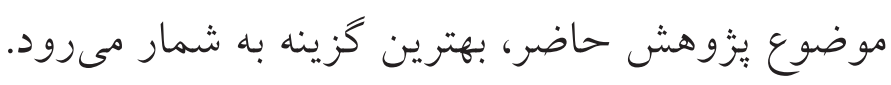

\section{سياستهاى داخلى آمريكا در قبال اسلام و مسلمانان}

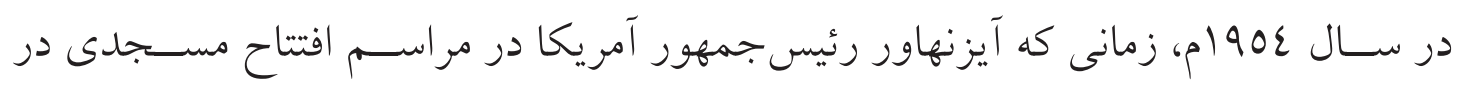

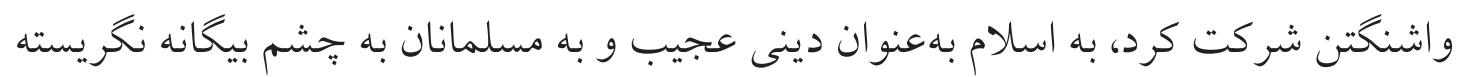

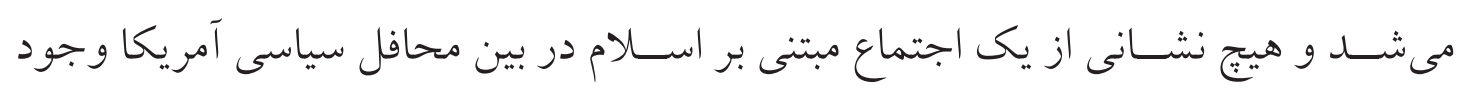

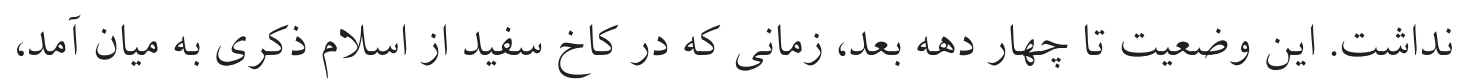

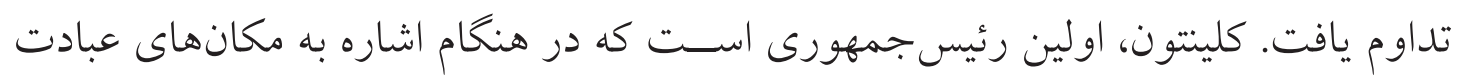

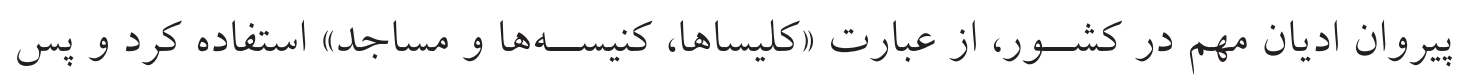

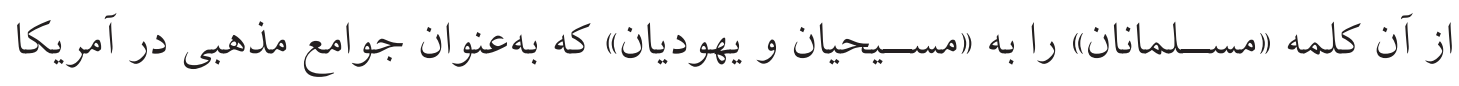

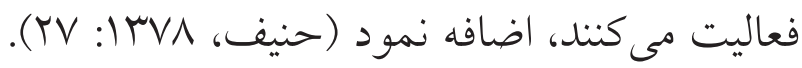

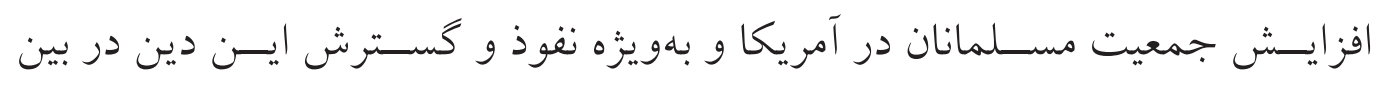


اقليتهاى جمعيتى در طى اين سـالها، حقيقتى انكارنشـــنى اســت. كُسـترش اين طبقه

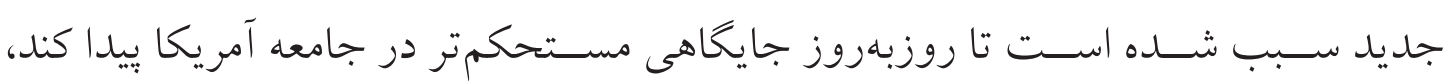

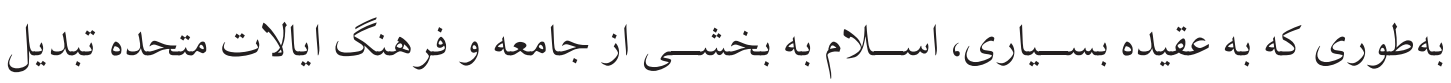

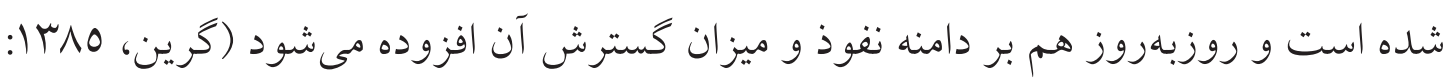

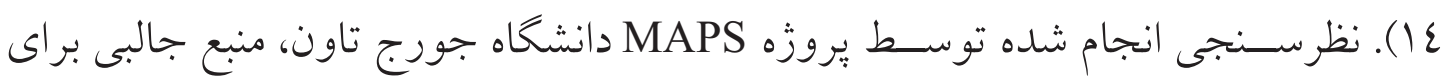

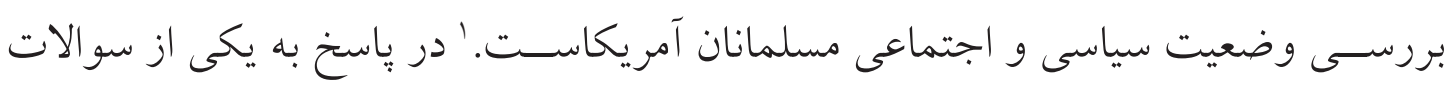

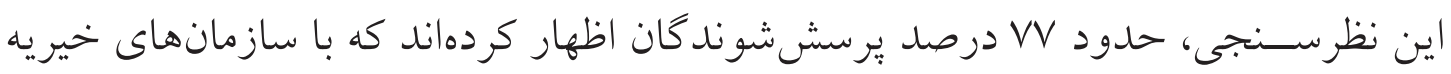

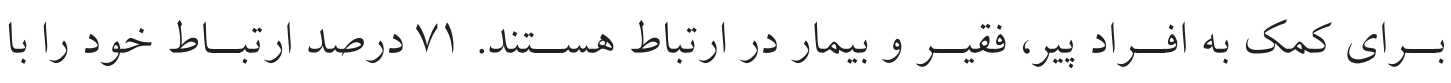

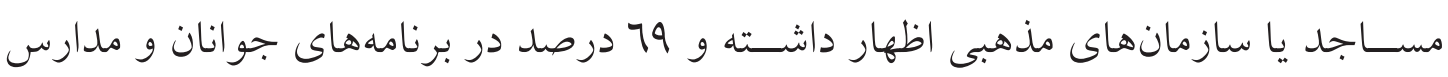

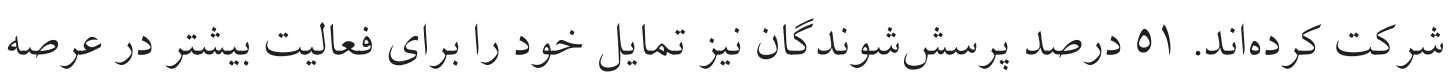

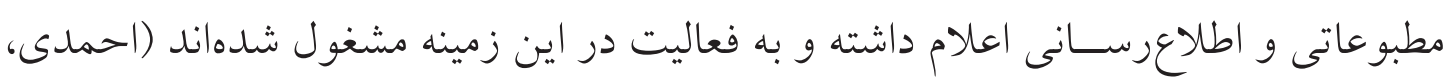

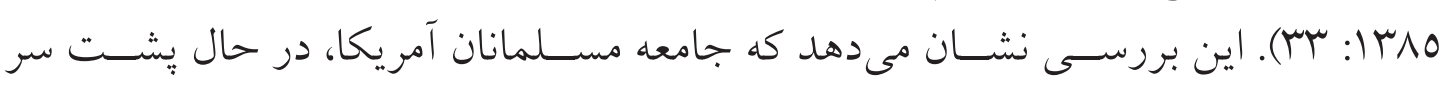

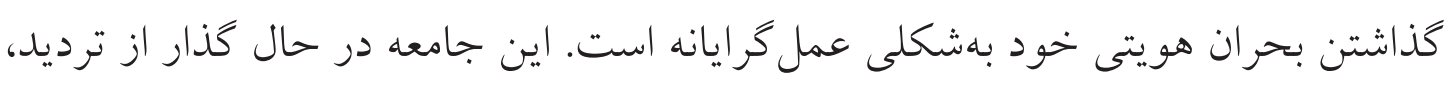

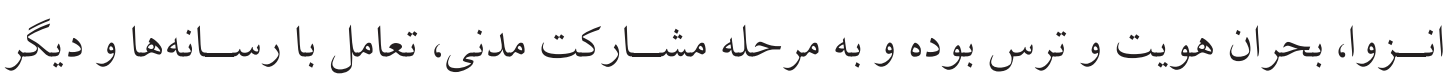

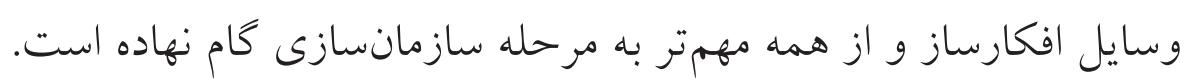

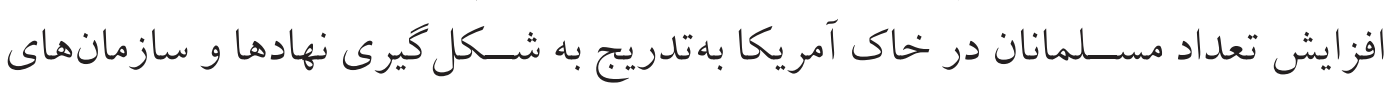

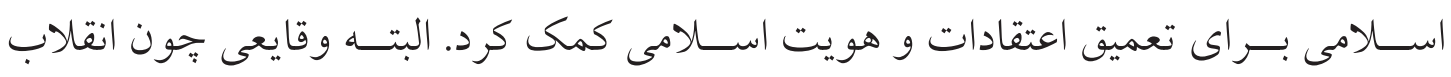

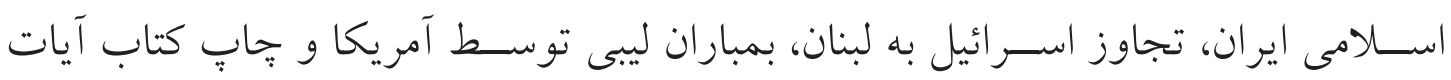

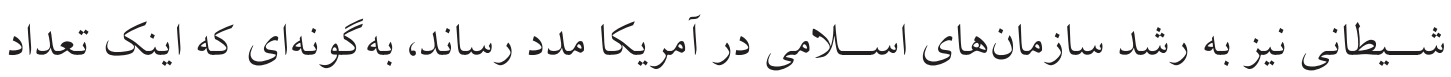

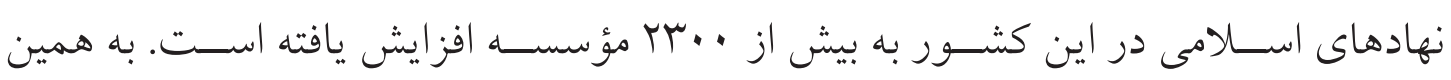

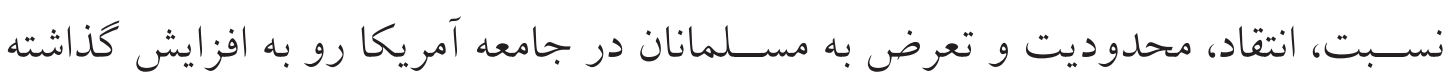

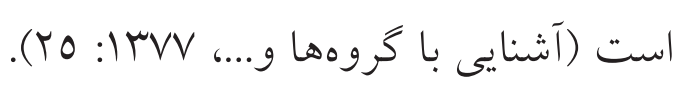

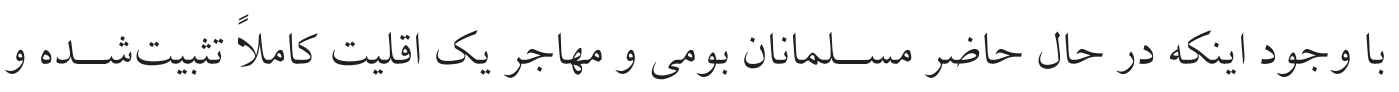

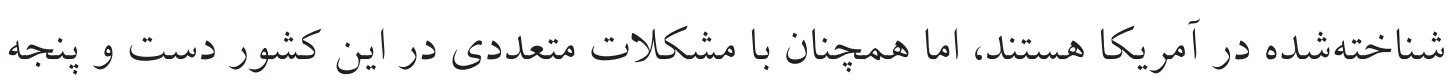

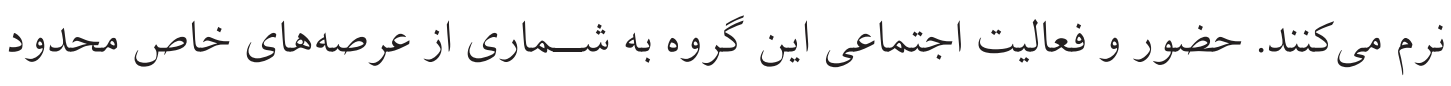

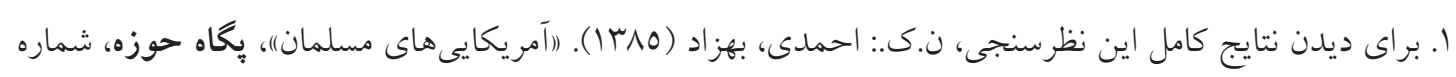


(e)

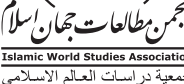
فصلنامه علمى - يُوهشى

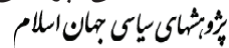

شـــه و در بخششهاى مؤثر سياسـى و راهبردى كشــور از حضور و اثربخشى آنان خبرى

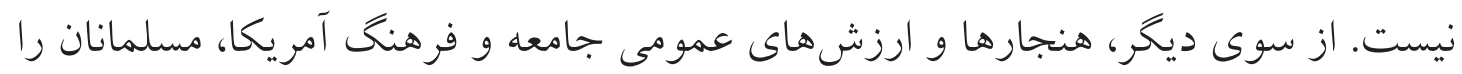

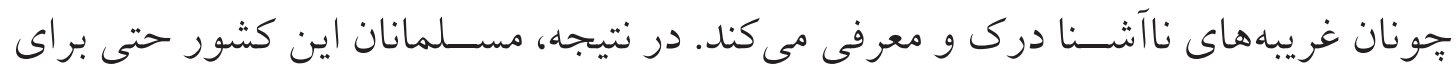

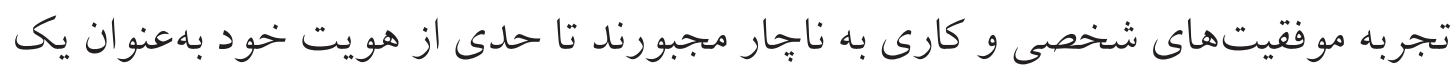

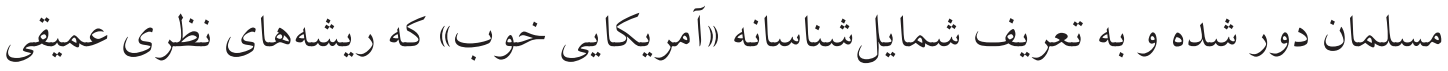

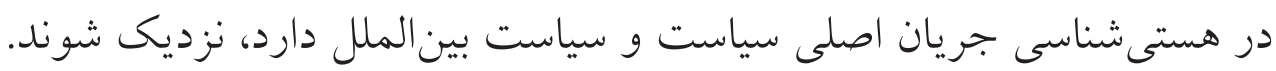

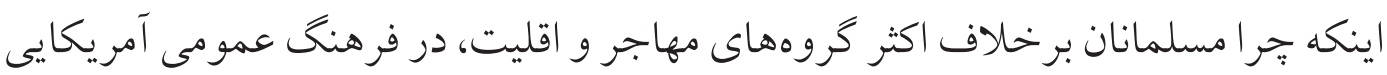

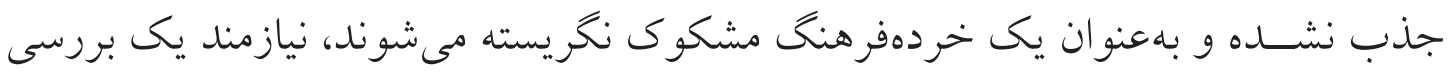

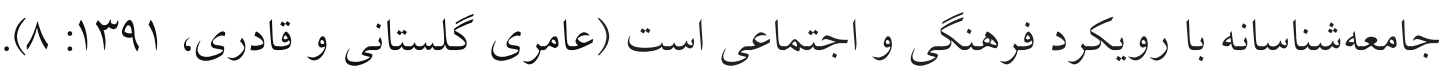

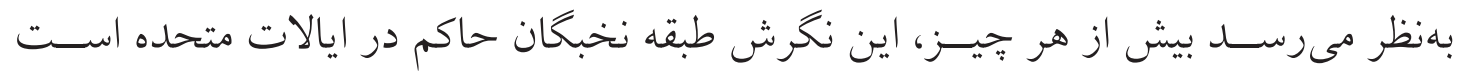

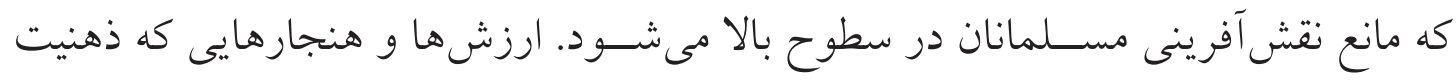

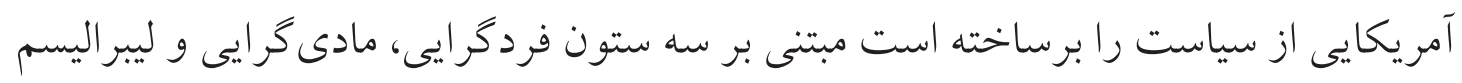

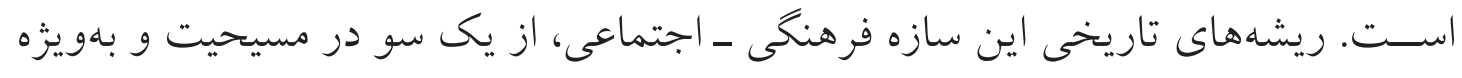

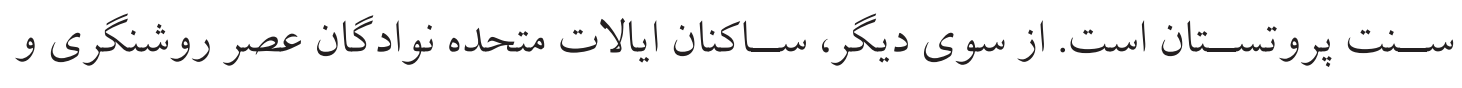

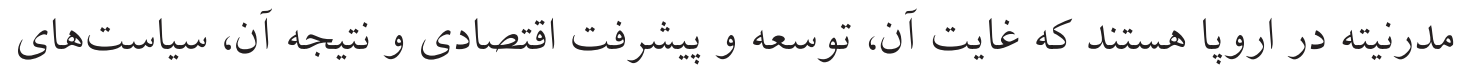

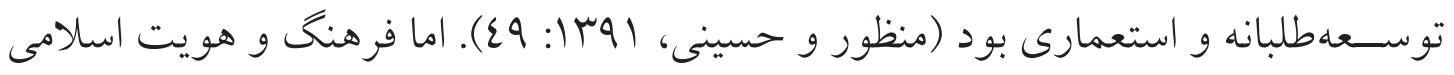

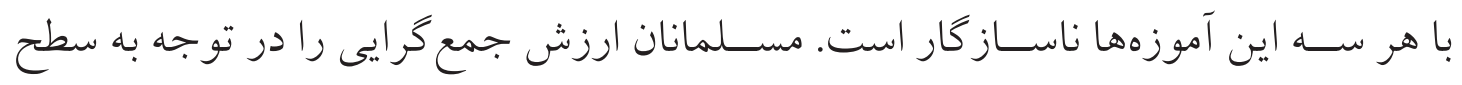

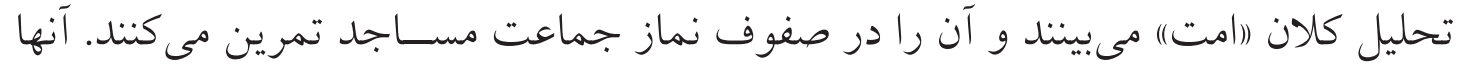

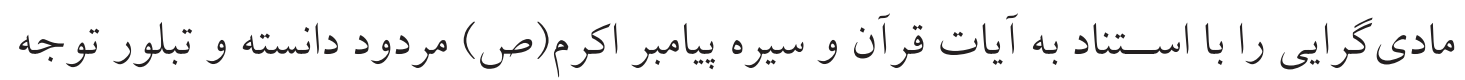

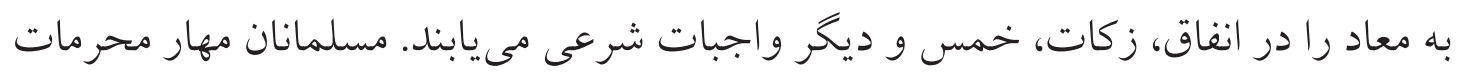

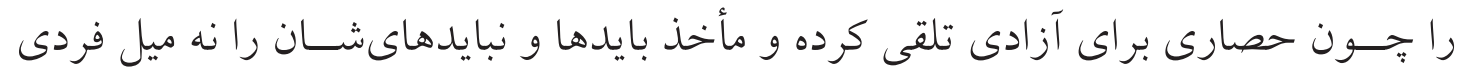

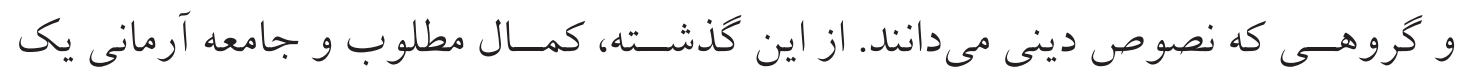

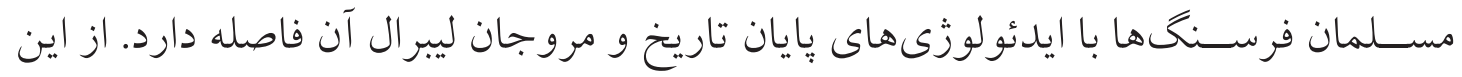

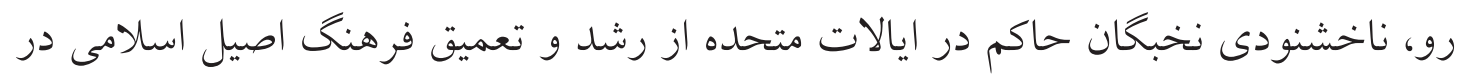

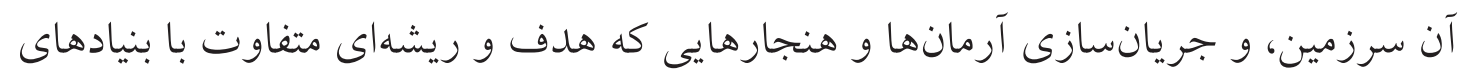

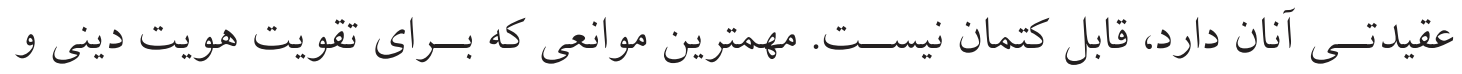

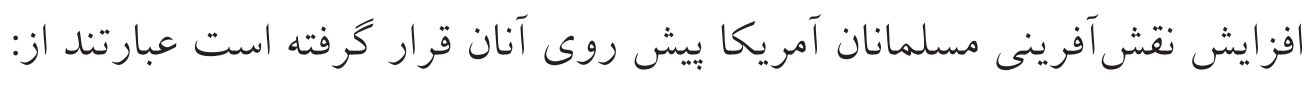


ا. ناآكاهى و ســــتبليغ نسـبت به اسـلام: بهرغم توسـعه و كسترش اسـلام، بيشتر

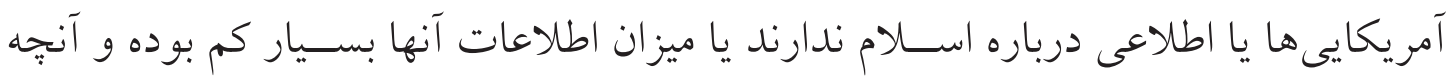

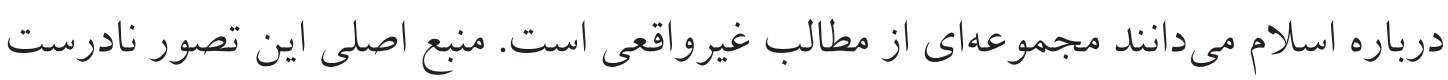

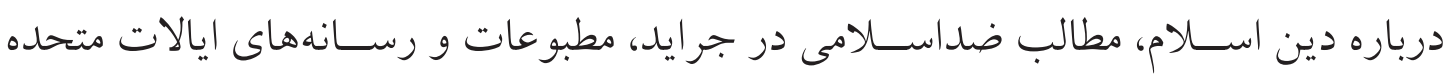

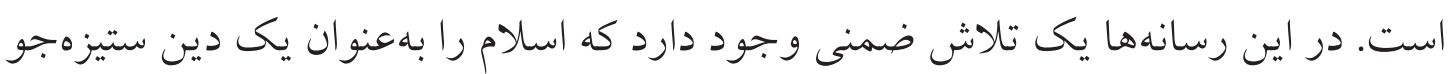

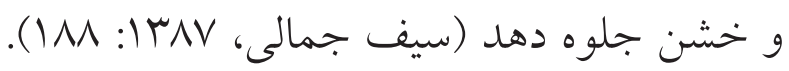

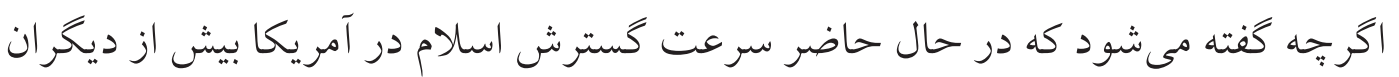

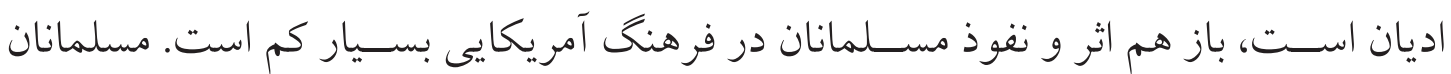

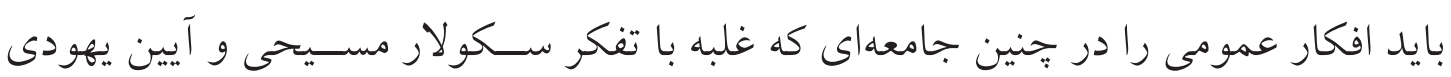

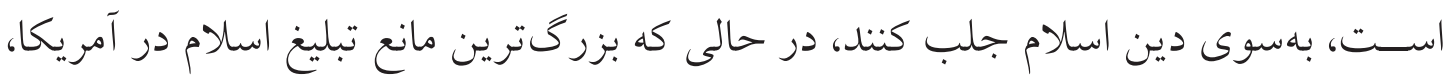

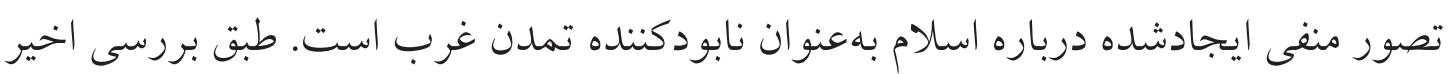

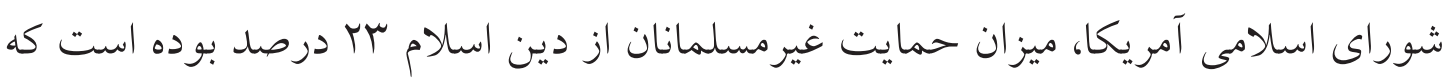

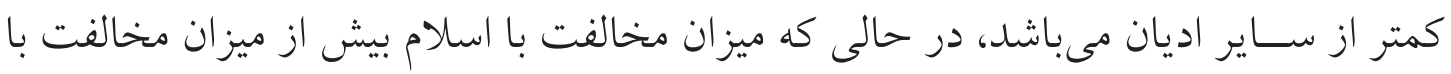

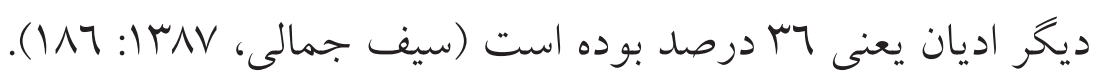

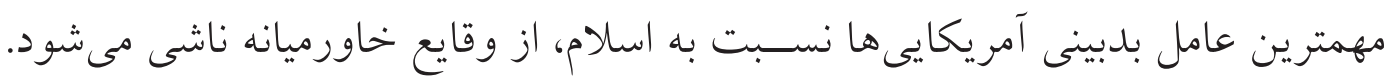

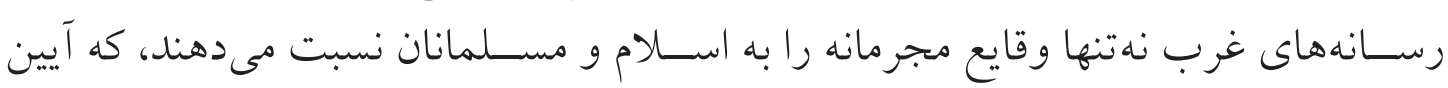

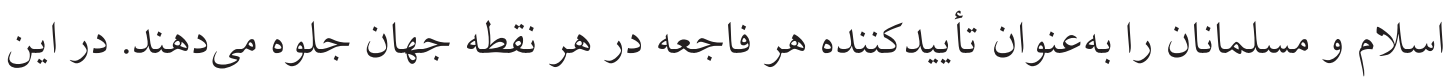

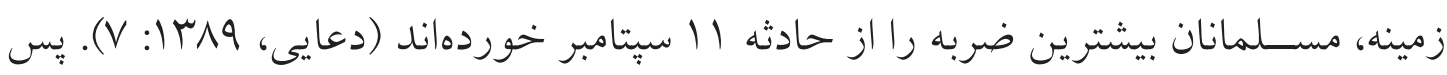

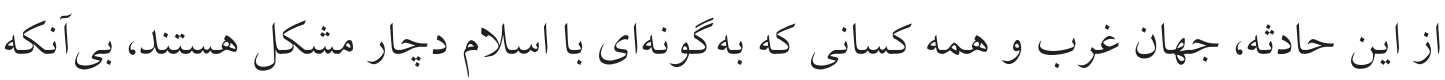

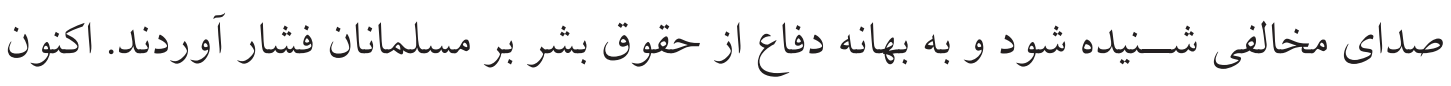

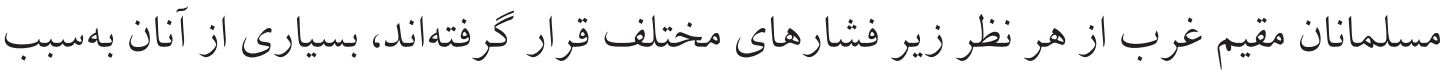

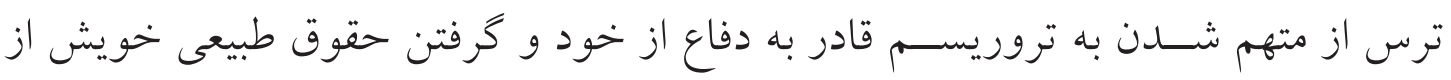

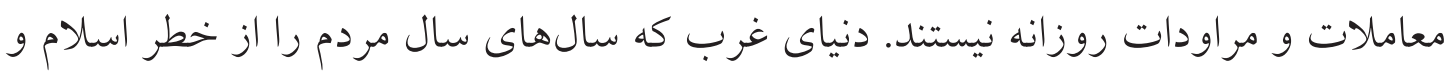

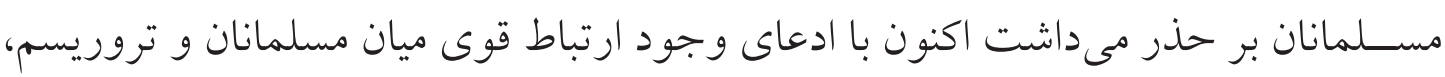

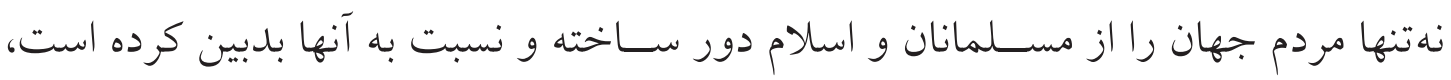

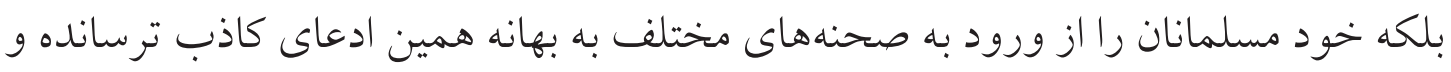

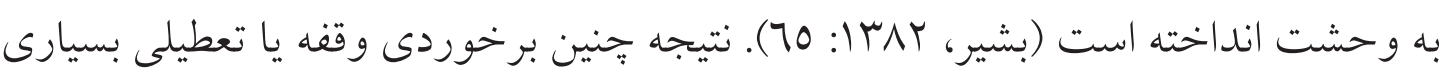


از فعاليتهاى طبيعى آموزشى، فرهنگى و اجتماعى بوده است. حتى روابط عادى مسلمانان

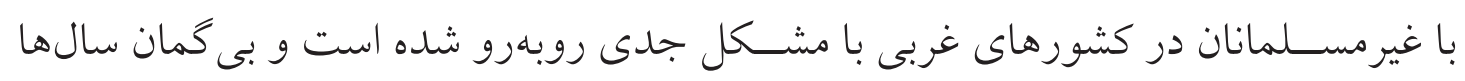
طول مى كشد تا وضع به حال عادى باز كردد.

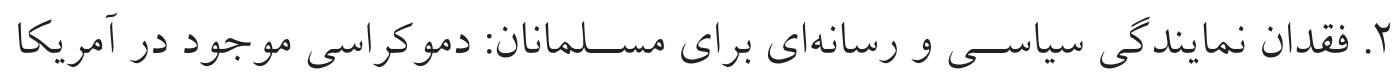

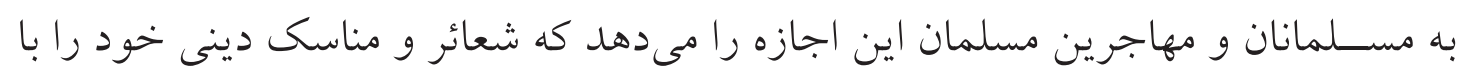

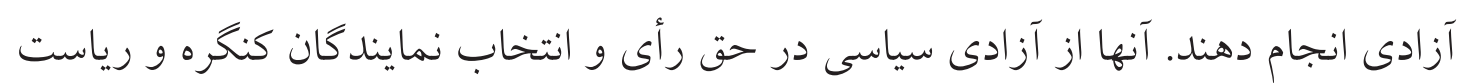

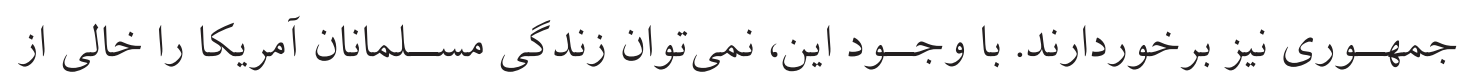

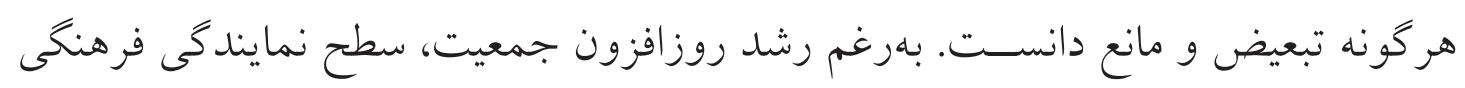

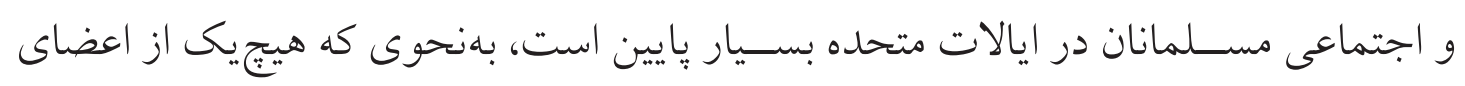

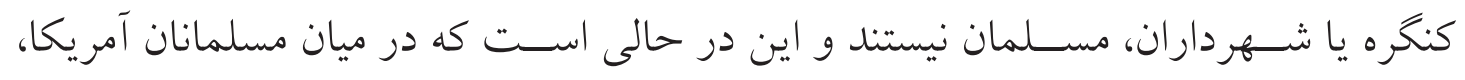
شخصيتهاى معروفى مانند محمدعلى كلى (بوكسور) و كريمعبدالجبار (قهرمان بسكتبال)

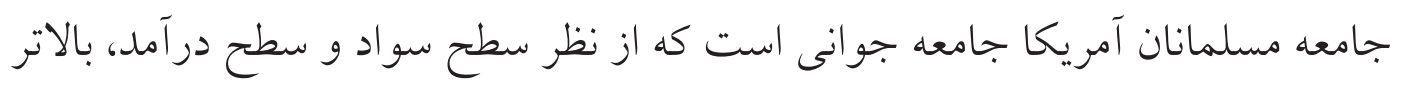

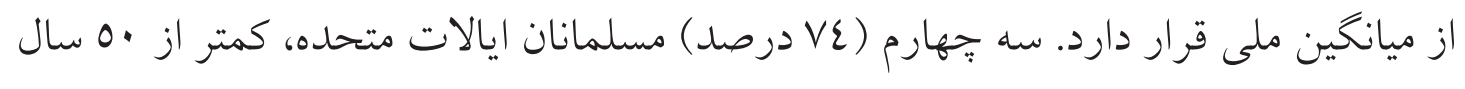

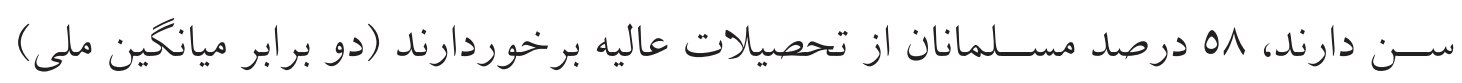

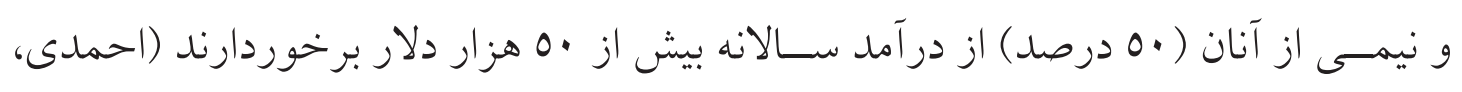

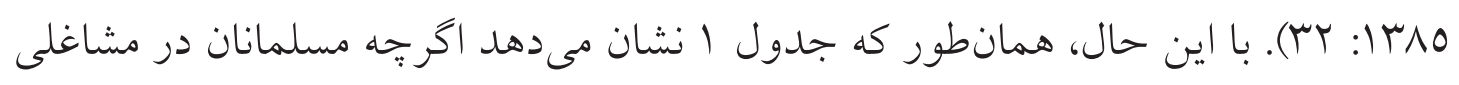

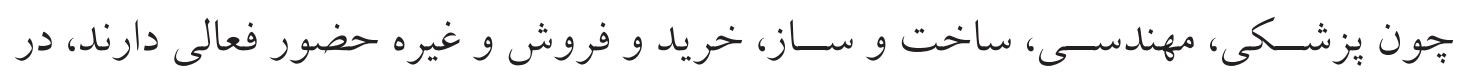

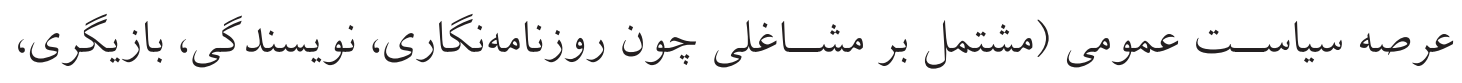

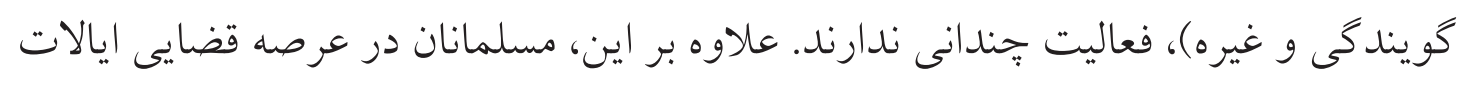

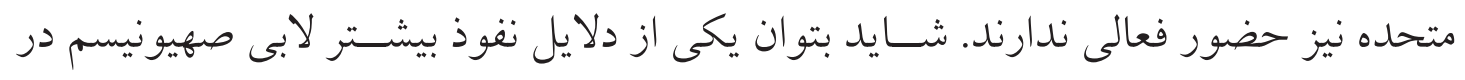

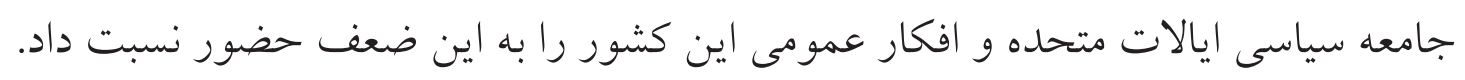


جدول شمارها - توزيع مشاغل در جامعه مسلمان ايالات متحده

\begin{tabular}{|c|c|c|c|}
\hline براكند درى & شغل & ير أكندگى & 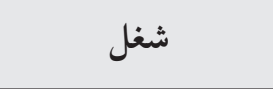 \\
\hline r & روحانى & ir & مديريت \\
\hline$r$ & توليد & 1. & يز شكى \\
\hline$\wedge$ & دانشجو & Tr & فنى / مهندسى \\
\hline 0 & باز نشسته & 0 & فروش \\
\hline 1 & خبرنغار & 1. & ساخت و ساز مسكن \\
\hline 1 & وكيل / قاضى & 7 & معلم / آموزش \\
\hline 9 & ديخر مشاغل & $\varepsilon$ & خدمات \\
\hline
\end{tabular}

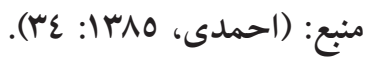

افزون بر اين، مسـلمانان مطبوعات مسـتقل و صاحب نفوذ نيز ندارند. در ميان صدها

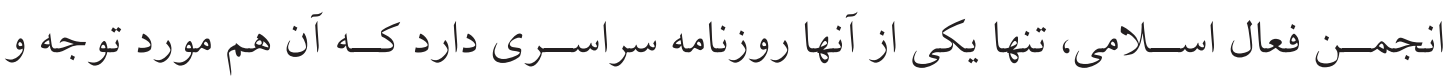

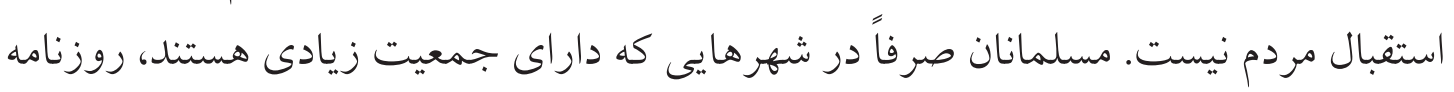

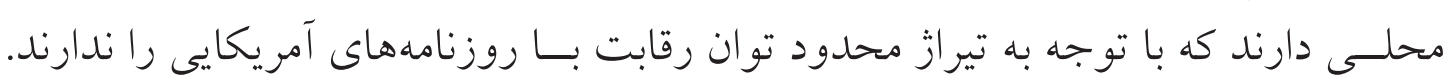
تنها رســانهاى كه تو انسته است تصويرى از مســلمانان ارائه بلدهد، شبكه الجزيره است كه

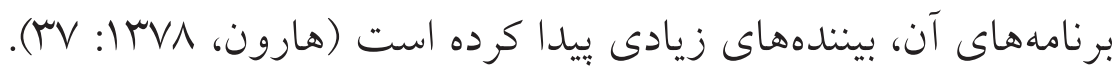

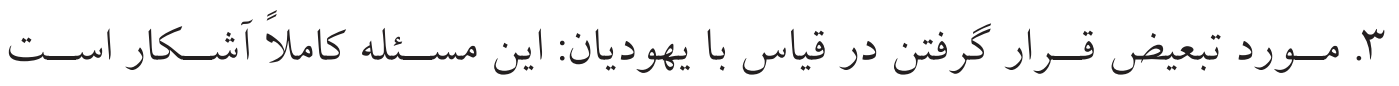
كه مســلمانان و يهوديان آمريكايى در اقتصاد و سياسـت از موقعيت يكسـانى برخوردار نيسـتند. يهوديــان در كنخره، نماينده و ســخنكو دارند، از امكانـات لازم براى تحصيلات بالاى دانشـحاهى بهرهمندند، در فعاليتهاى اقتصادى، در رسانههاى گروهى، در مؤسسات

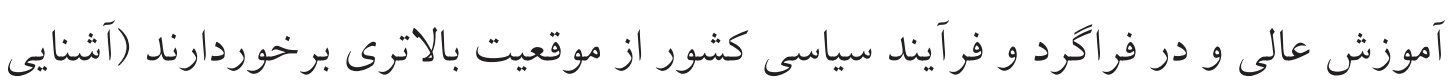
با كروهoا و..... يكى از برنامههاى سياسـتمداران مغرض و علماى متعصب غربى تلاش براى جدايى

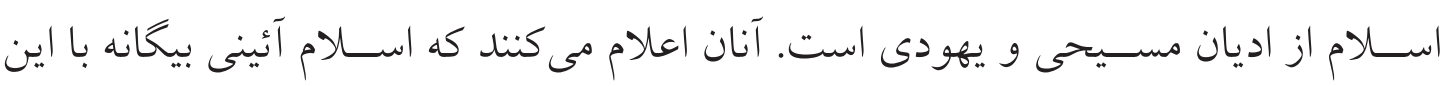
دو دين اسـت و با ميراث آنها ارتباطى ندارد. در تحقيقات و مطالعات دينى اى كه توســط آمريكاييــان صورت كرفته و مى گيرد، اسـتعمال مكرر كلمه (يهودى مسـيحى)" در توضيح 
اديان آسمانى يكى هدف عمده دارد و آن منزوى كردن اسلام و جدا كردن آن از ساير اديان

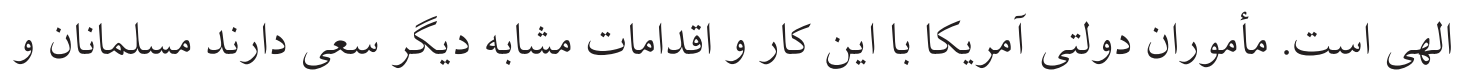

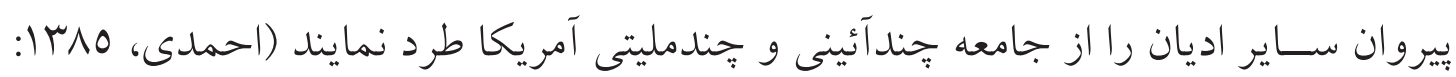

ترديدى نيست كه تلاش بسيارى براى تحريف و بد جلوه دادن جهره اسلام در آمريكا،

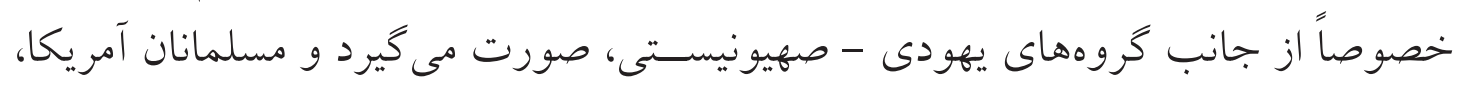

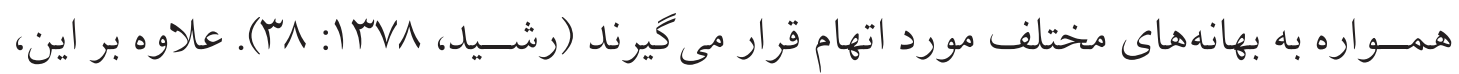

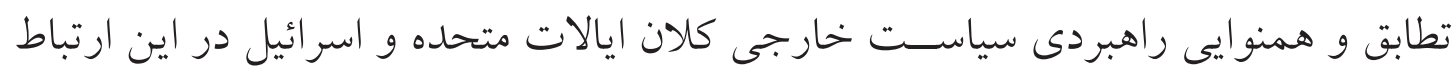

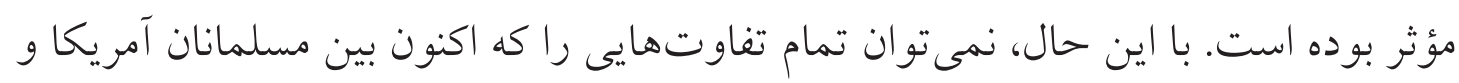

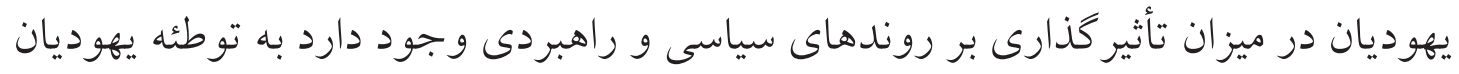

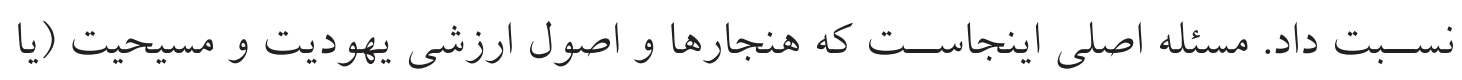

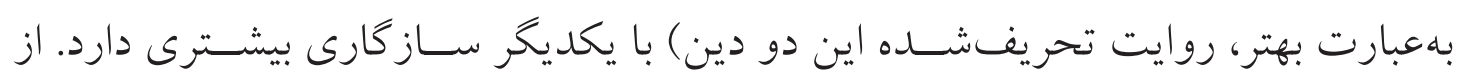

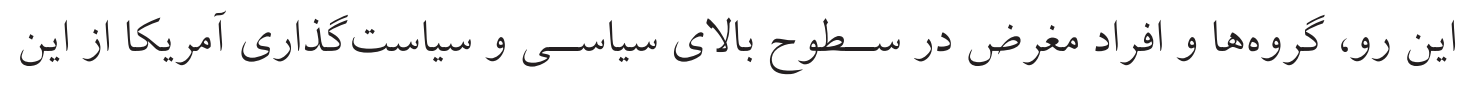

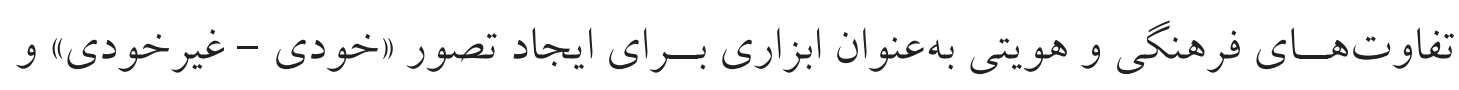

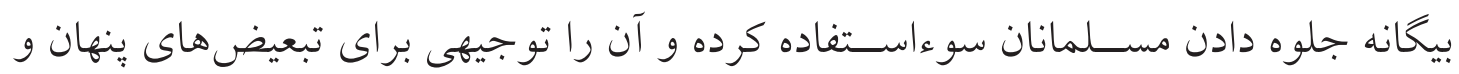
آشكارشان نسبت به اسلام و مسلمانان مى دانند.

\section{سياست خارجى}

از آغاز ييدايش اسلام، غرب همواره متأثر از اسلام بوده است، اما بررسى و مطالعه جوامع

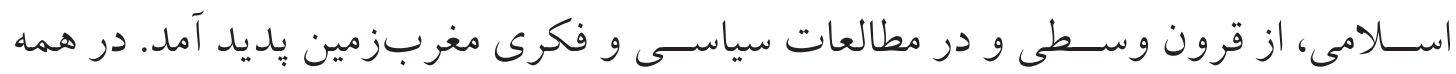

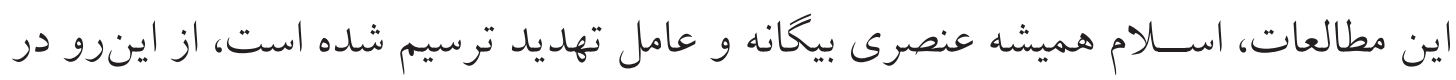

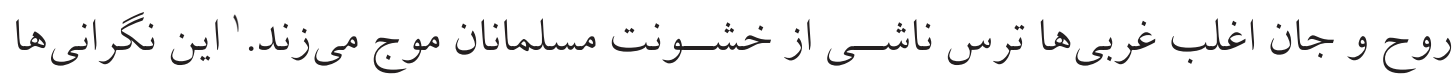

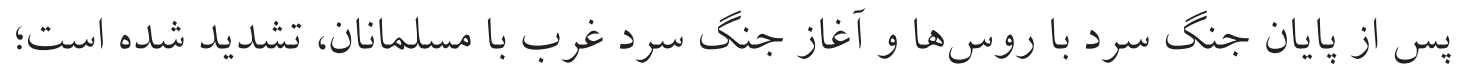

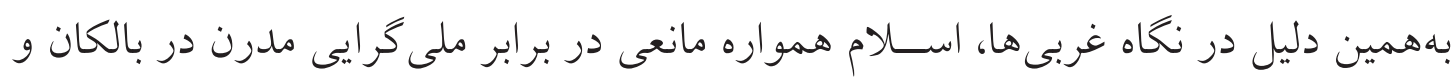

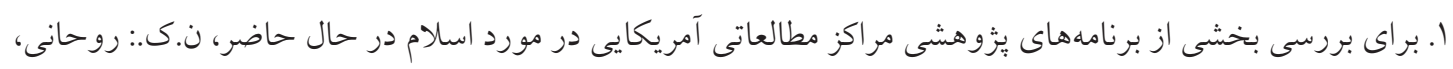

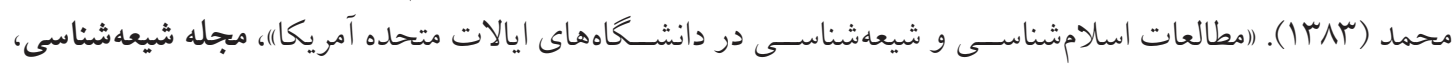
شماره 0. 


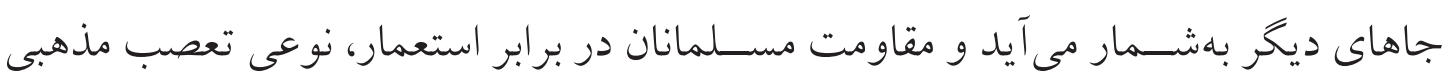

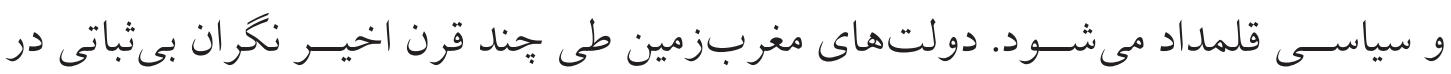

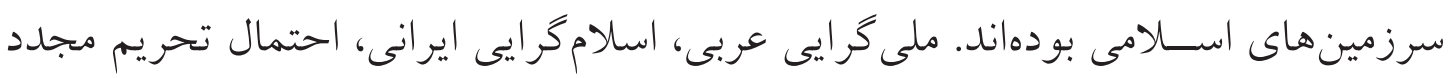

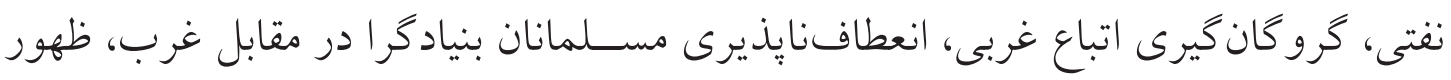

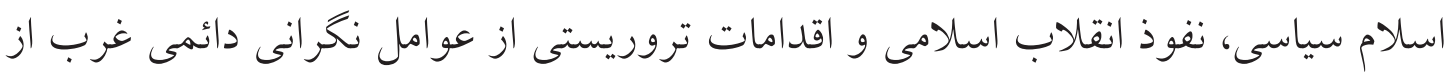

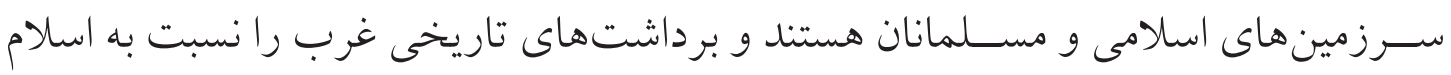

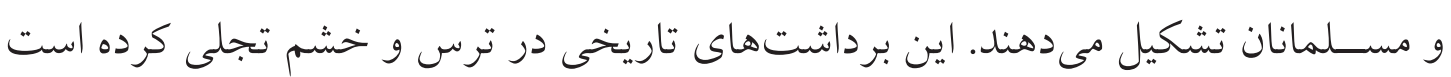

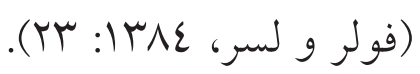

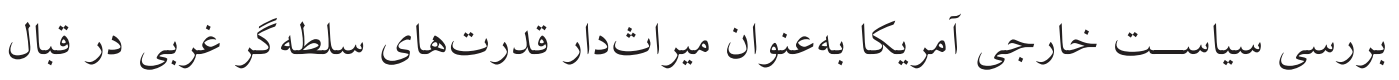

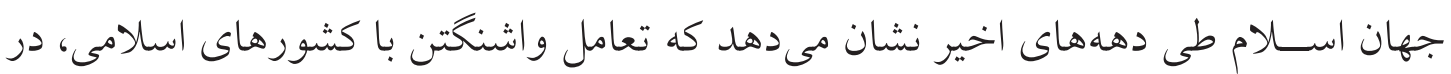

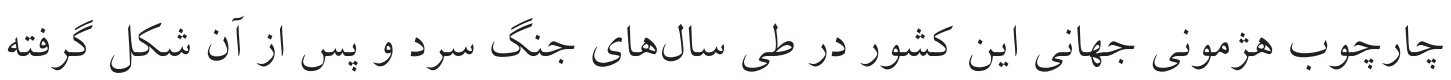

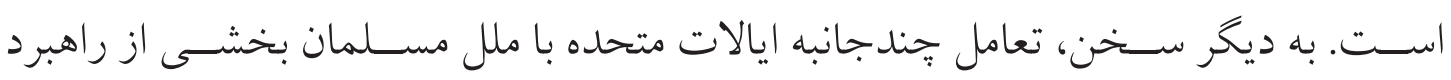

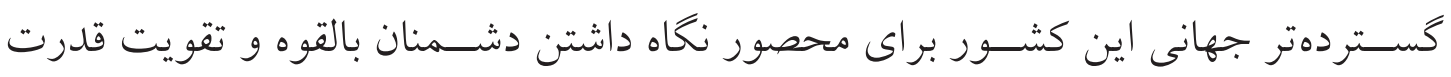

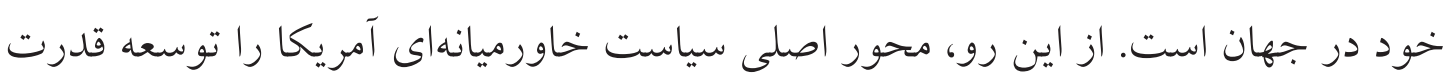

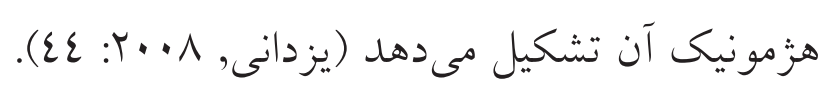

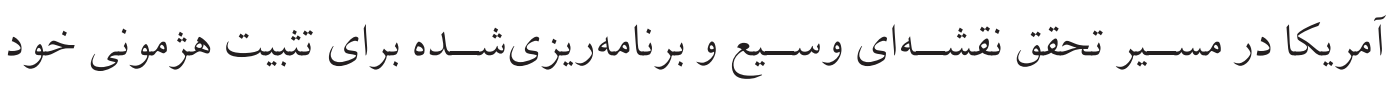

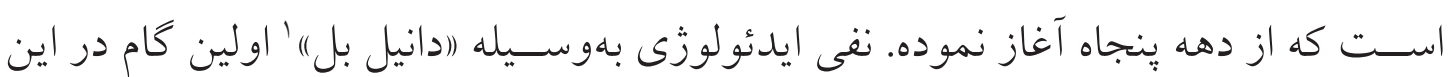

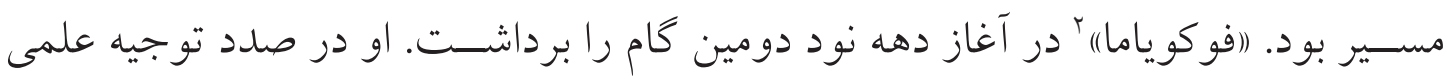

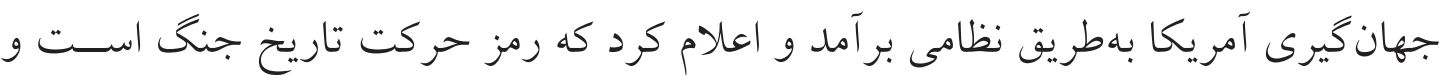

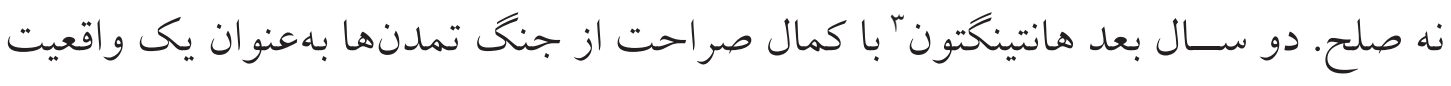

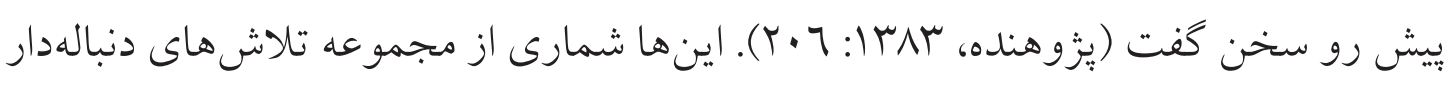

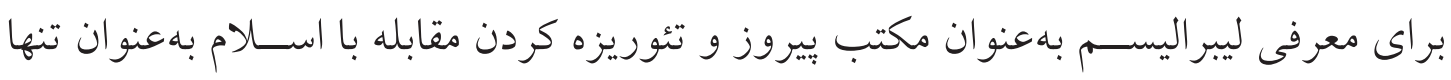
هماورد محتمل است.

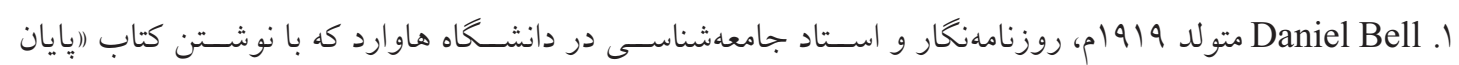
| ايدئولوزى" به شهرت رسيد.

2. Francis Fukuyama.

3. Samuel P. Huntington. 
بهنظر مى رســـ دولت آمريكا براى حفظ تسـلط بر خاورميانــه، بهعنوان مهمتر ين كام

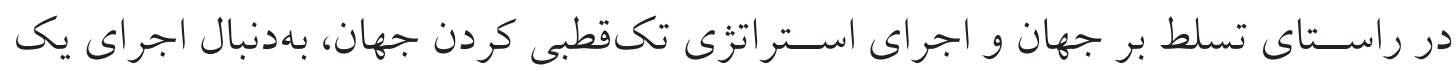

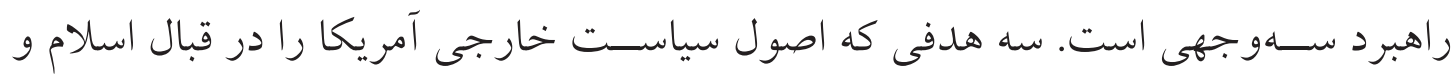

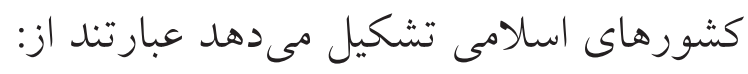

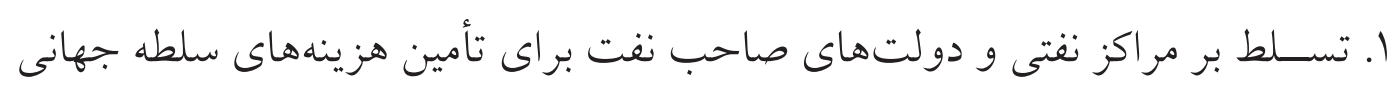

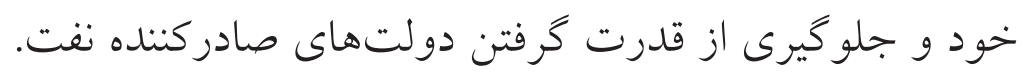

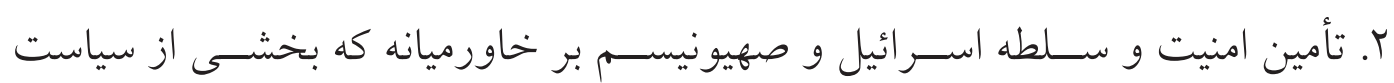
مشترى جهانى آمريكا است. r. مهار و يا انحر اف اسلام سياسى و كنترل جنبش هاى اسلامى بـ براى جلو كيرى از نفوذ

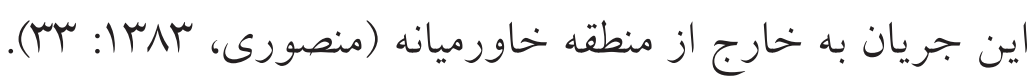

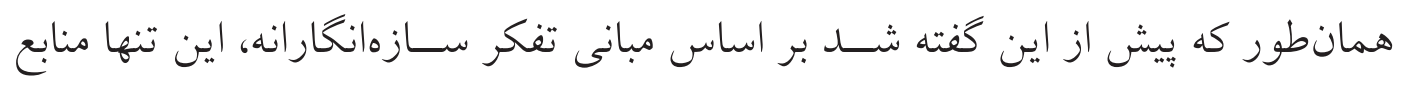

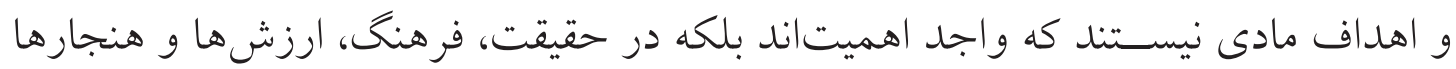

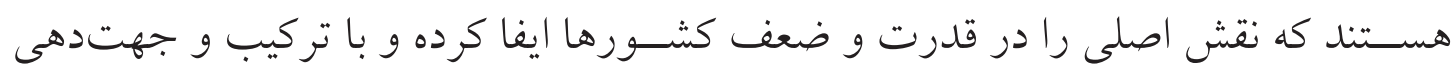

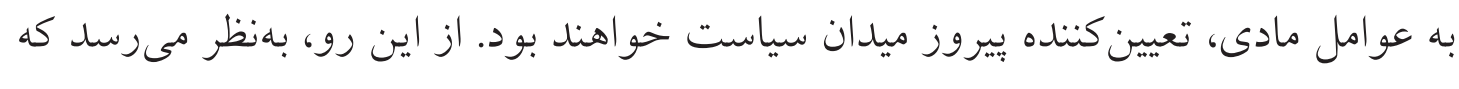

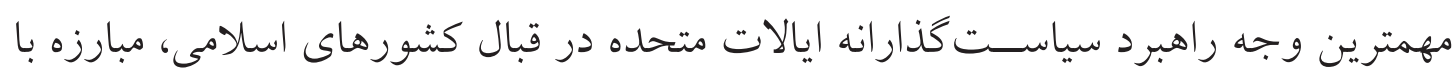

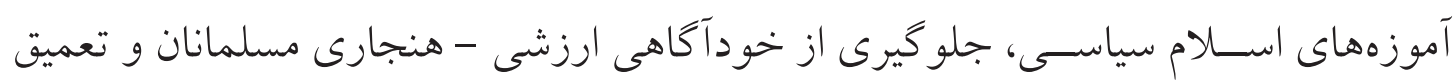
هويت دينى آنان است.

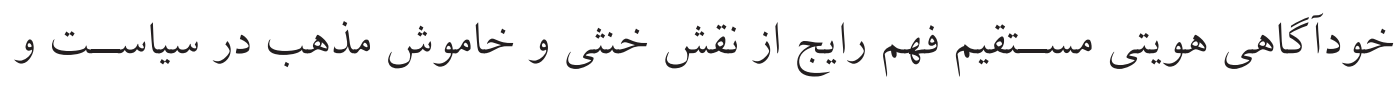

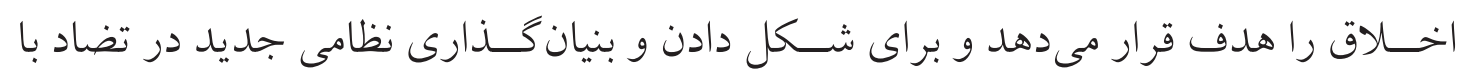

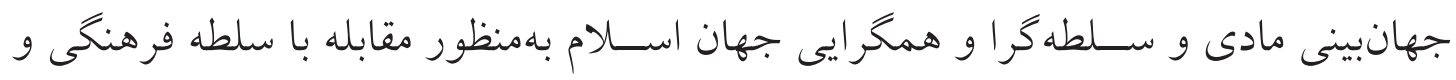

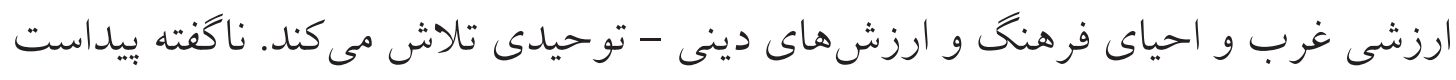

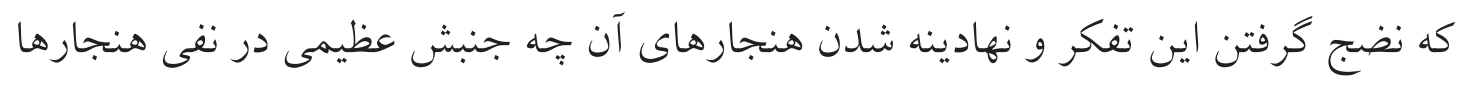

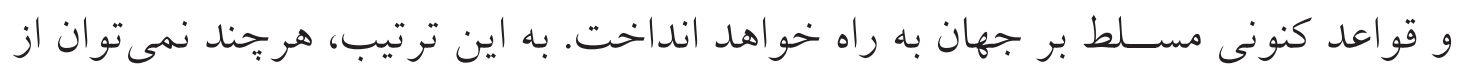

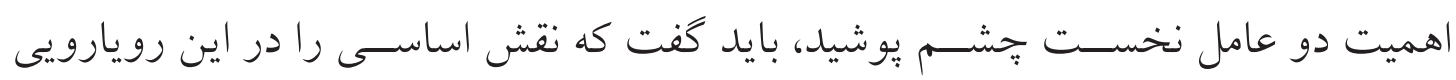

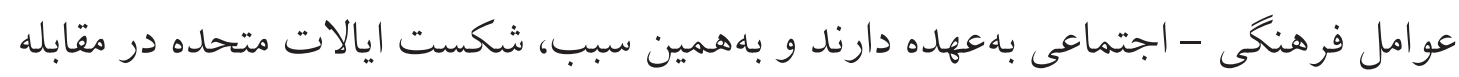

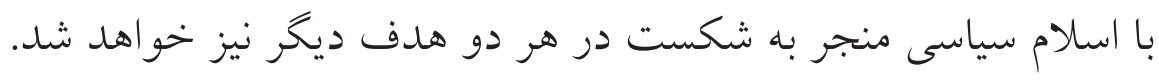

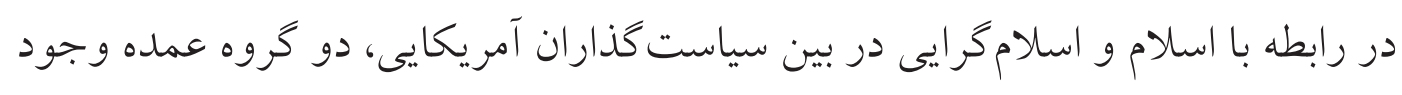




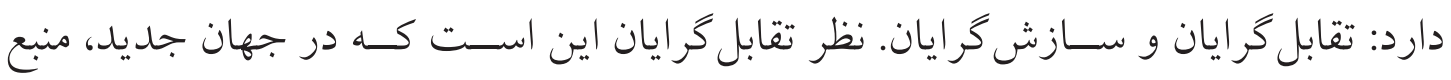

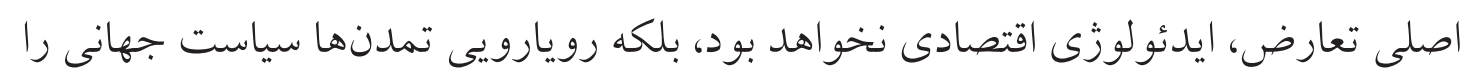

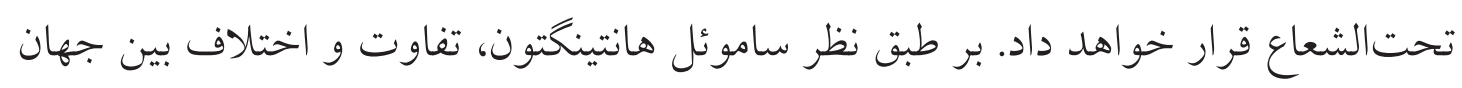

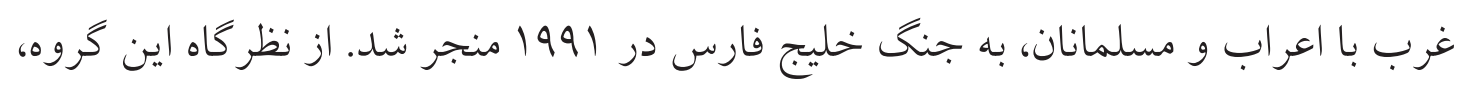

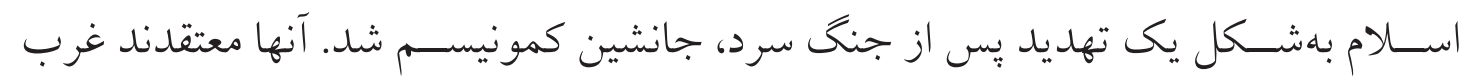

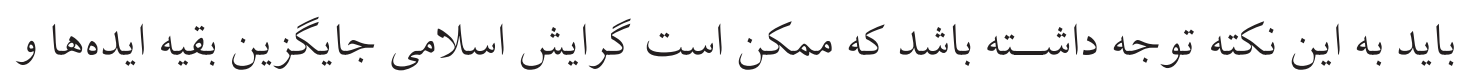

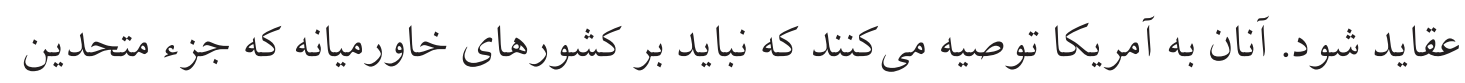

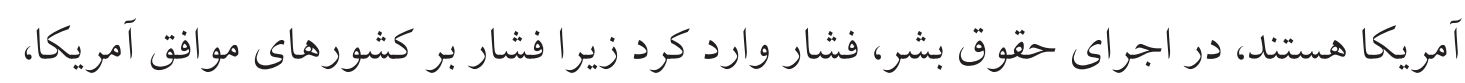

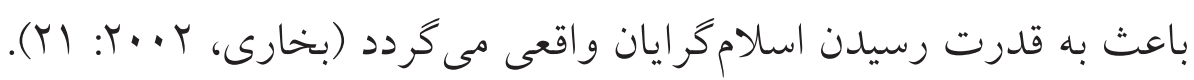

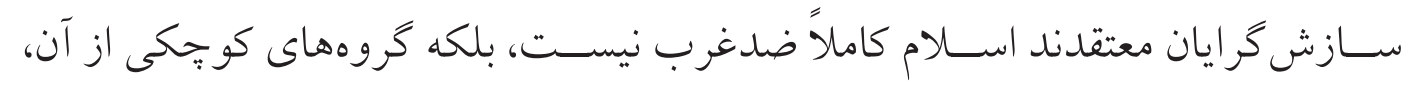

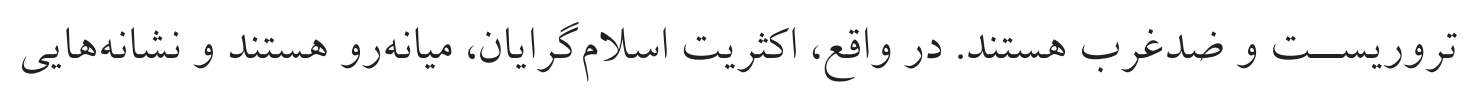

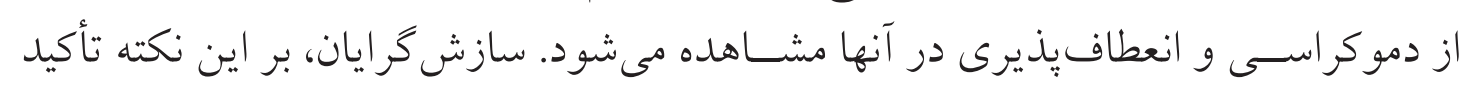

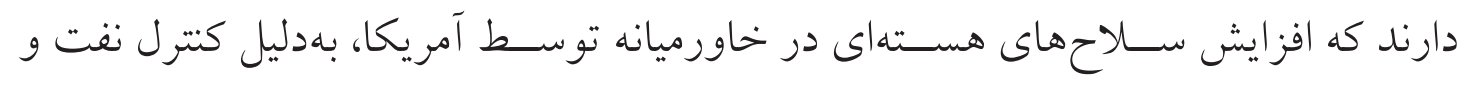

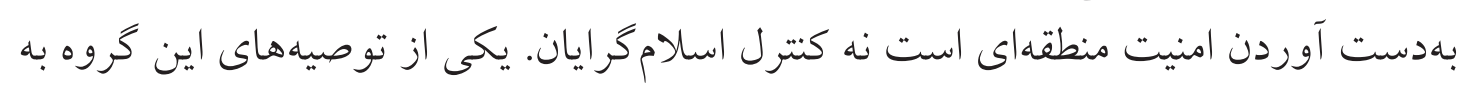

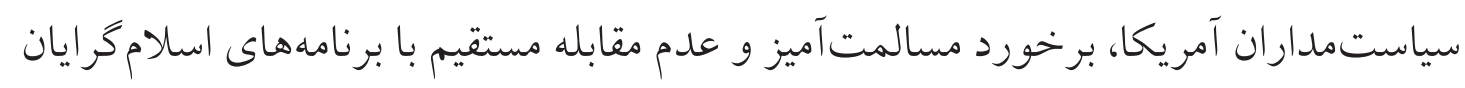

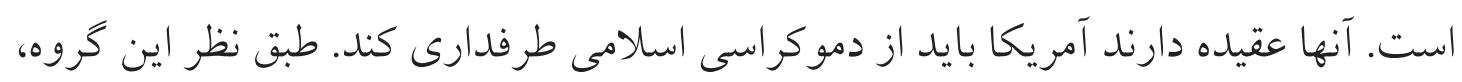

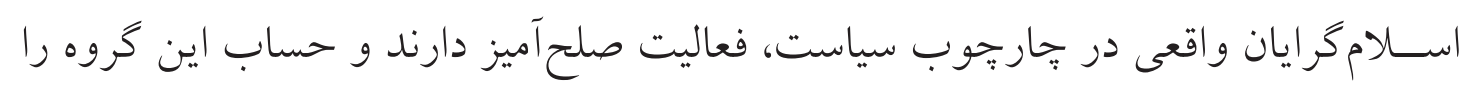

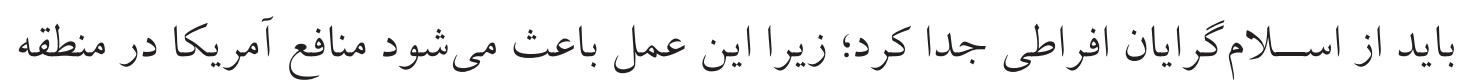

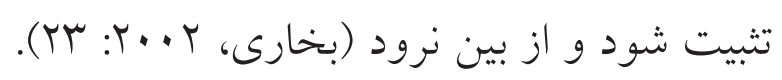

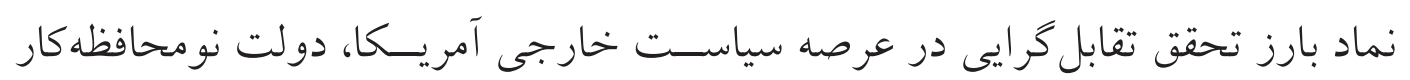

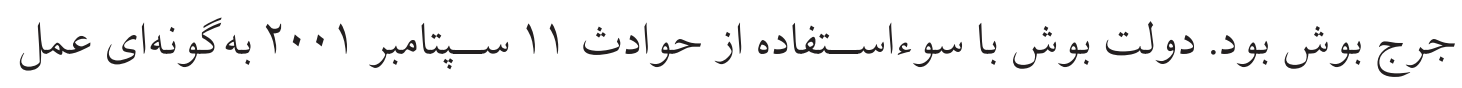

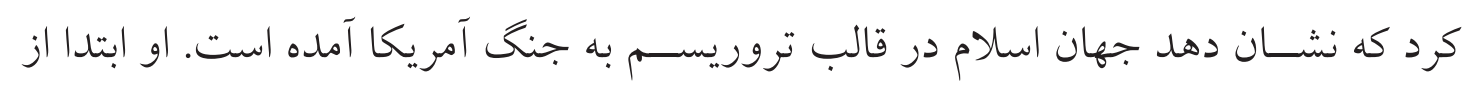

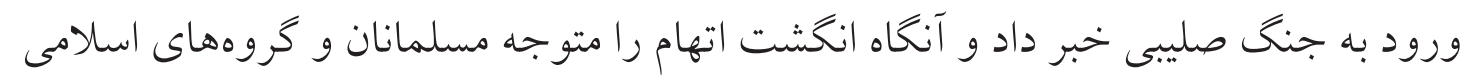

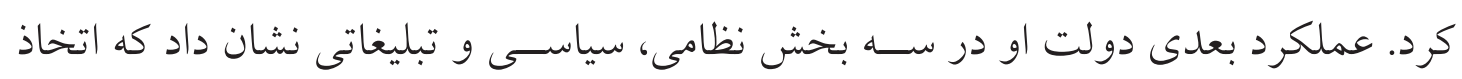

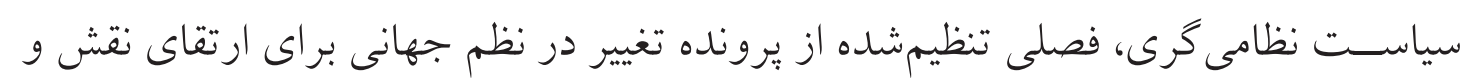

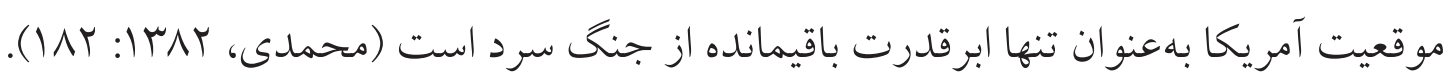

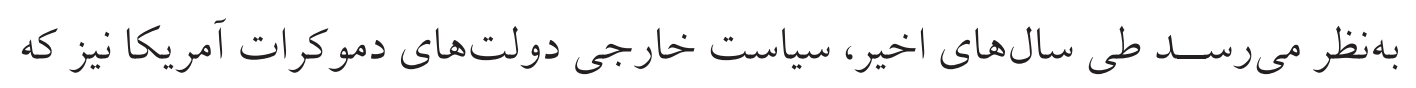


(2),

Iflamic World Studies Association

فصلنامه علمى - يُّوهشى

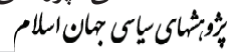

Irv

قرار اسـت رويكرد ســازش گرايانه داشته باشــند، بر مبناى تقابل و تضاد با اسلام ـ البته با تفاوتى تاكتيكى ـ شكل كرفته است. كلينتون در 1992 در مجلس اردن كفت: (ادر خاورميانه رقابت بين استبداد، آزادى، وحشت، امنيت و ... مبارزهاى قديمى است). او حرفى از اسلام

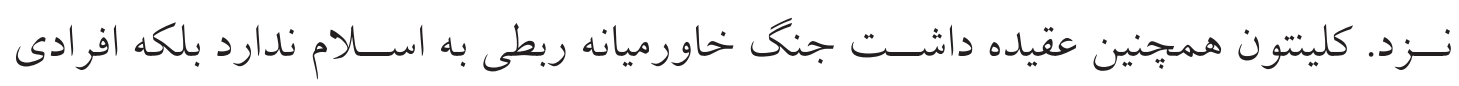
هسـتند كه خود را در رقابت الفاظ مذهبـى و ملى قرار مى دهند، در صورتى كه نه مذهبى

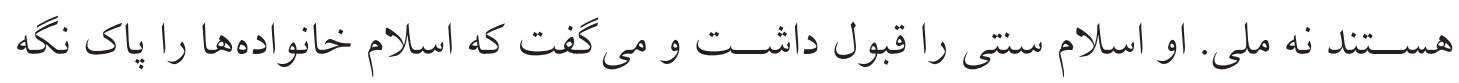
مى دارد و جون سياسى نيست، براى آمريكا هم خطرى ندارد و ما با اسلام سنتى بهصورت دهورت

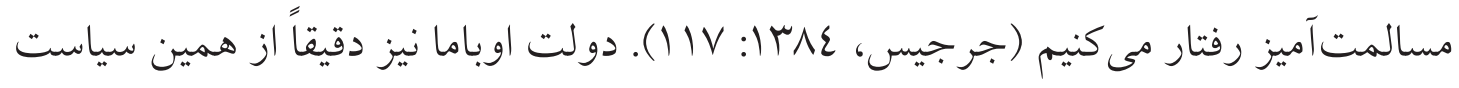
رياكارانه بيروى مى كند. سخنرانىهاى احترامَآميز اوياما در مورد اسلام و مسلمين در قاهره

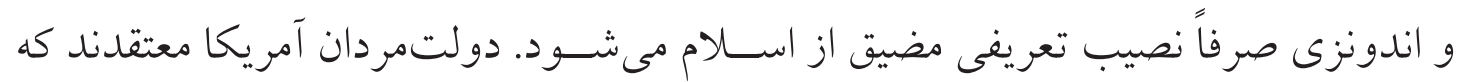

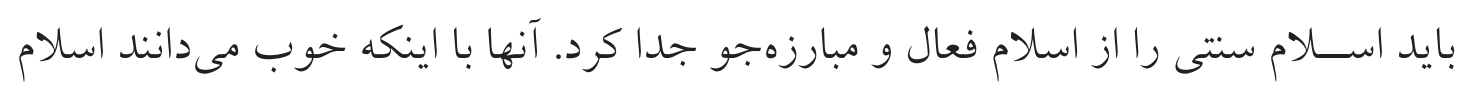

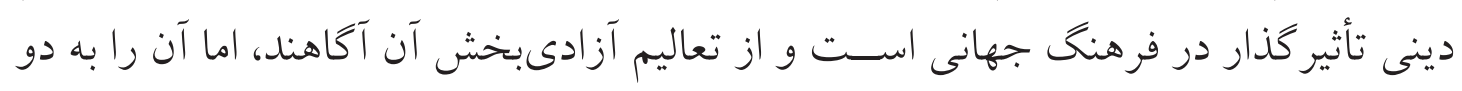

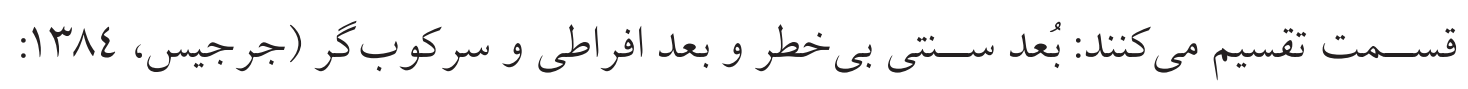

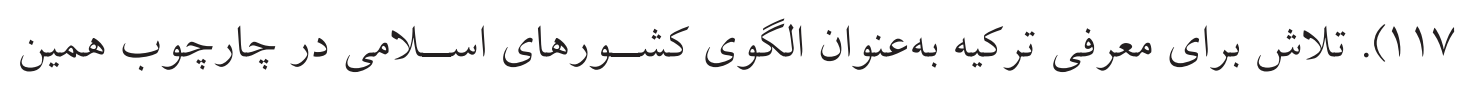
سياست انجام مى شود.

إحياى هويت اسلامى و ايدئولوزى هوني

سياستمداران غربى همواره با نخرشى خاص به هويت اسلامى نخريسته و در ينى تبليغ

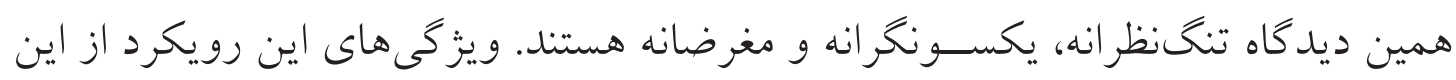
قرار است:

اول آنكه، از دنياى اسـالام و مســلمانان از جمله گروههاى اسـالام گر ا، تصويرى ثابت، ايسـتا و غيريويا ارائه مىشــود كه كمتر ارتباط و تعاملى با دنياى بيرونى دارد؛ كويى اسلام و فرهنخ اسلامى يديدهاى استثنايى است كه فارغ از شر ايط اجتماعى، سياسى، اقتصادى و بشرى به حيات خود ادامه مىدهد.

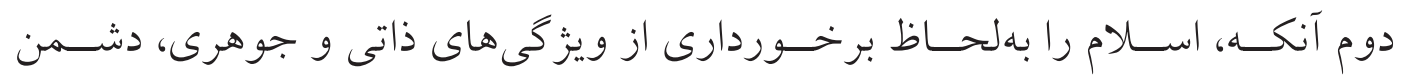
دموكراسى، نو گرايى، آزادى و بويايى معرفى مى كنند. درحقيقت بديده اسلام گر ايى، ديخرى غرب قلمداد مىشود كه همواره با آن در كشمكش و نزاع است. يس اسلام و اسلام كرايان نمى توانند با ارزش هاى دنياى كنونى همساز شوند.

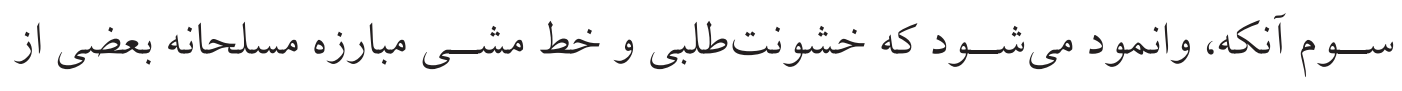


كروههاى اسلام كرا بيش از آنكه ريشه در واقعيتهاى اجتماعى، سياسى و اقتصادى داشته

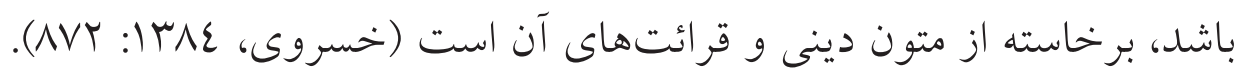

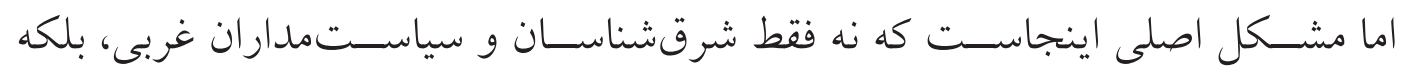

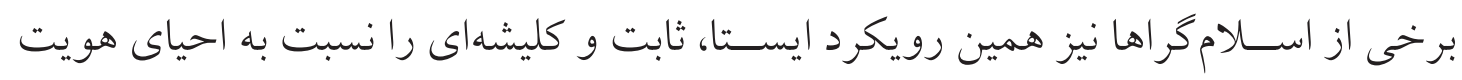

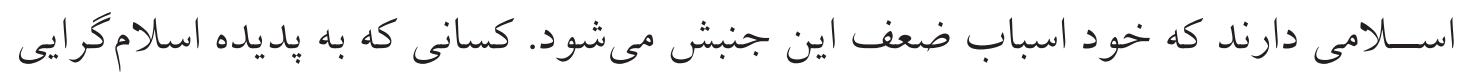

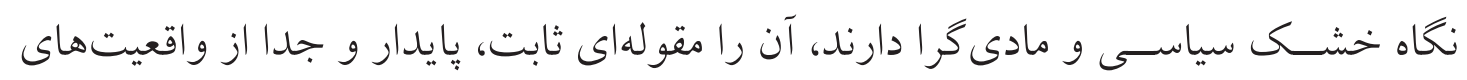

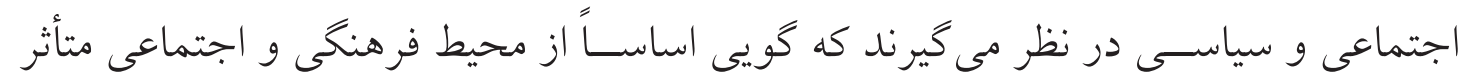

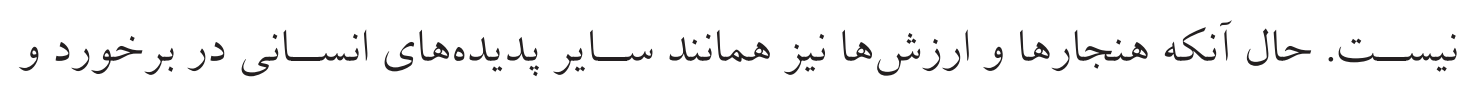

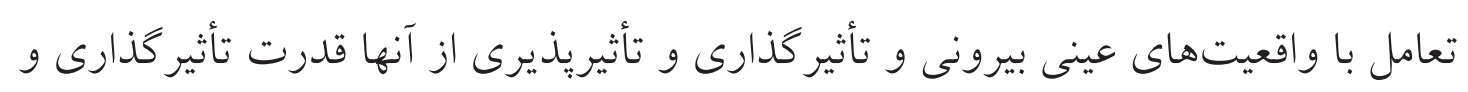

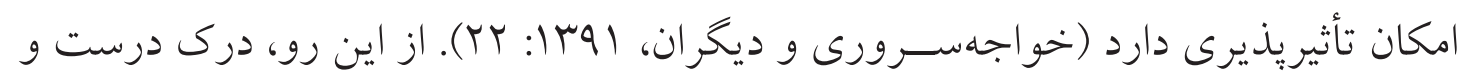

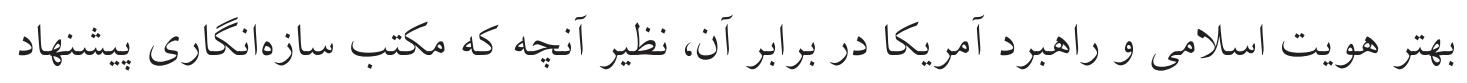

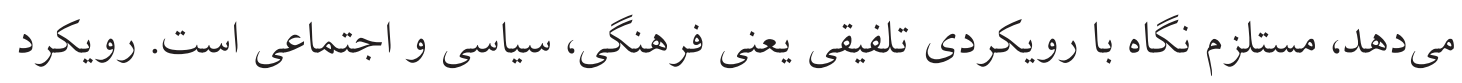

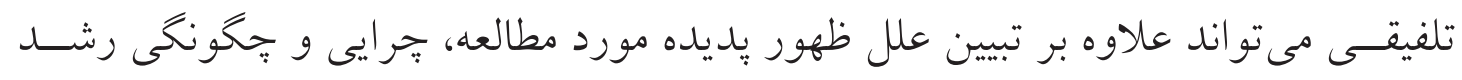

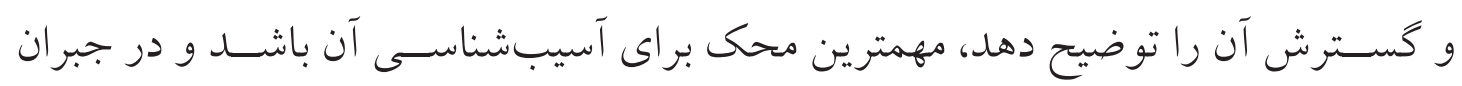

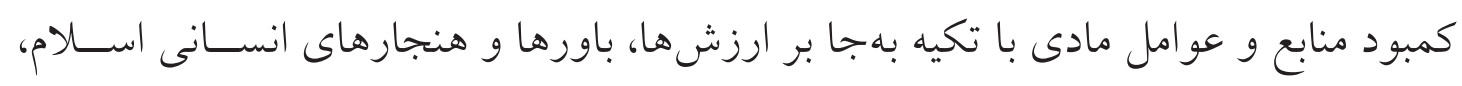
راهشا باشد. 


\section{نتيجه كيرى}

آيا اين تنها ايالات متحده اسـت كه نكران وجود يكى اقليت مذهبى و فعاليت آن در كشور

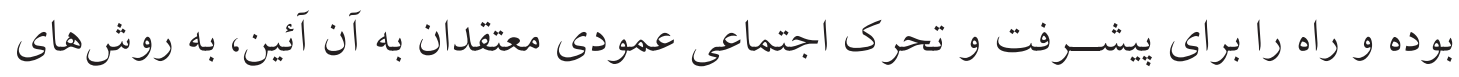

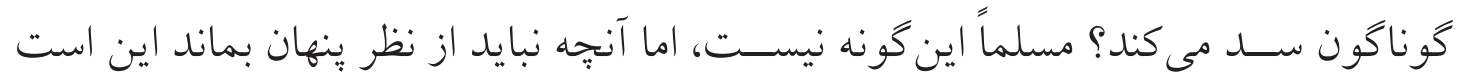

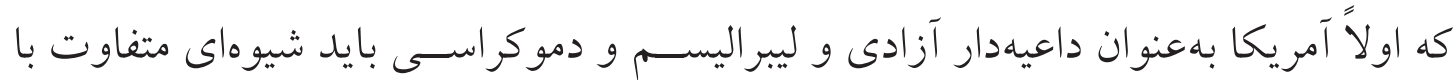

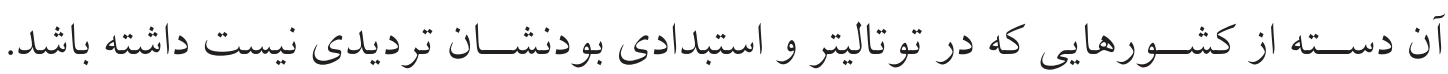

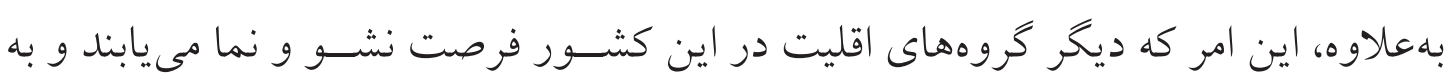

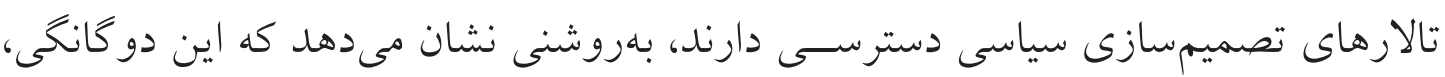

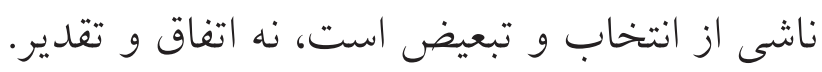

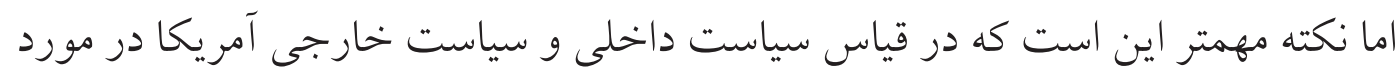

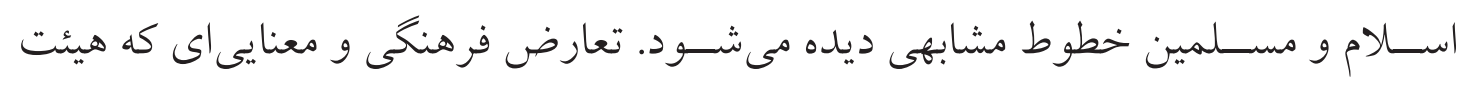

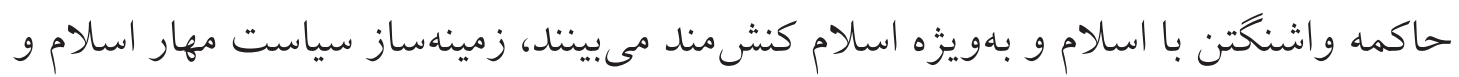

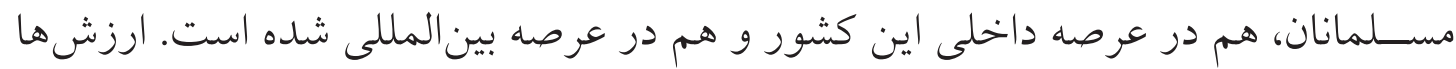

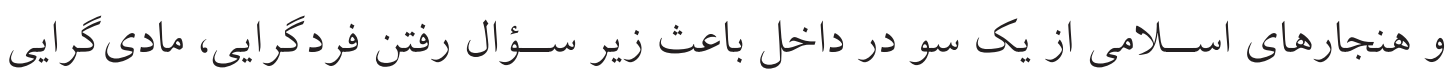

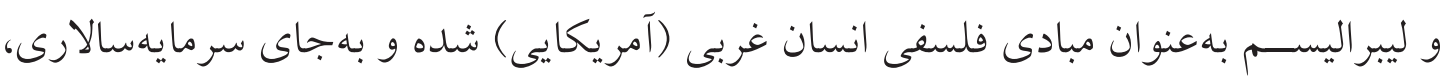

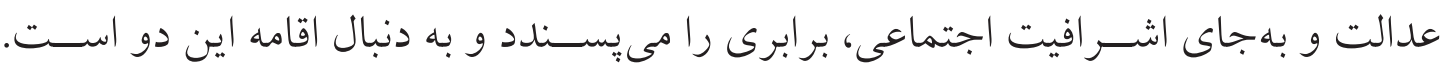

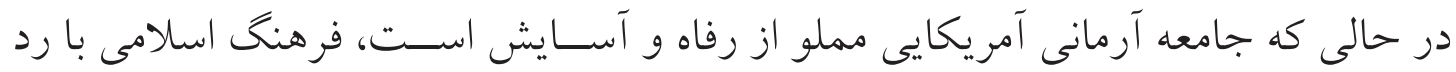

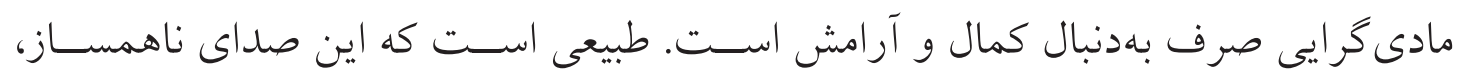

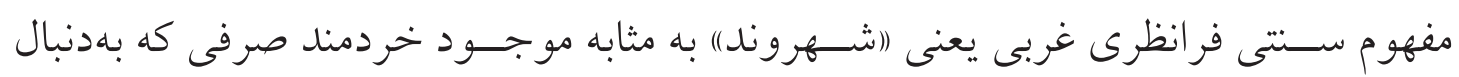
كسب حداكثر لذت است را زير سؤال مىبرد.

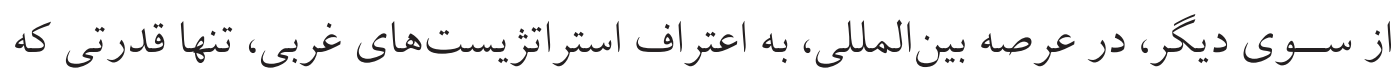

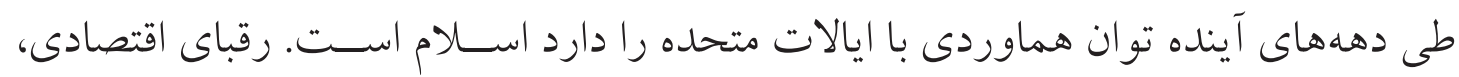

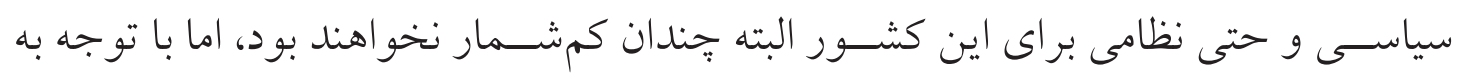

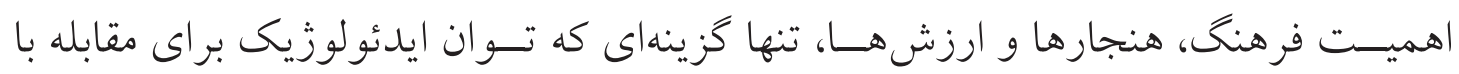

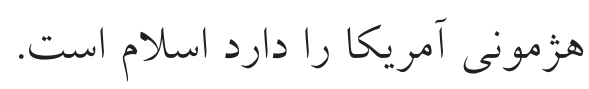

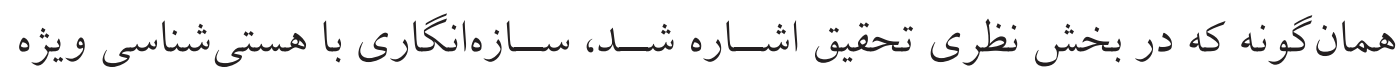

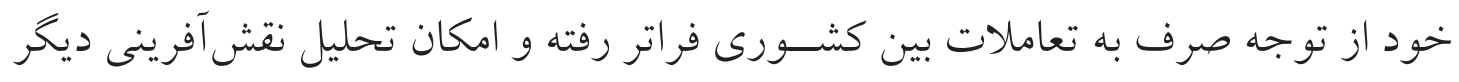




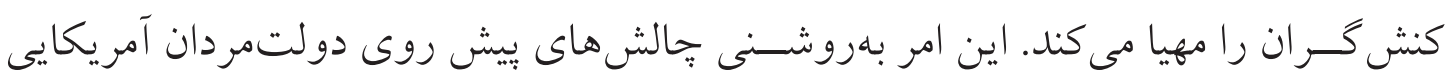

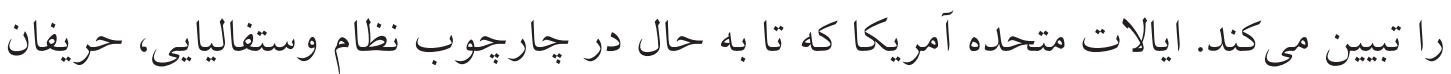

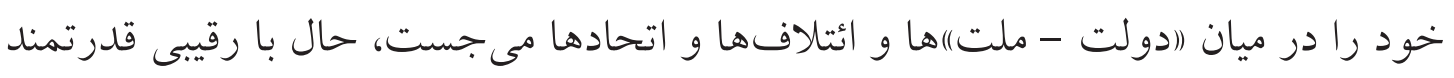

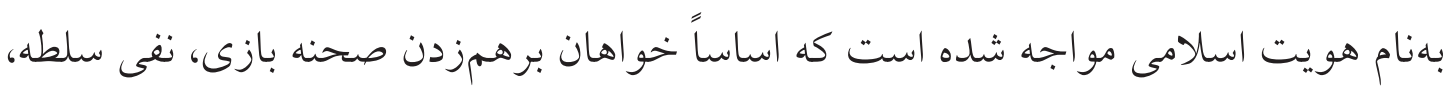

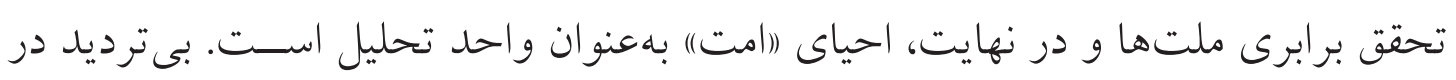

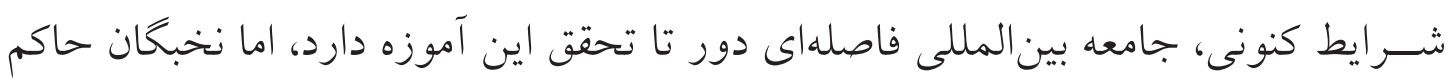

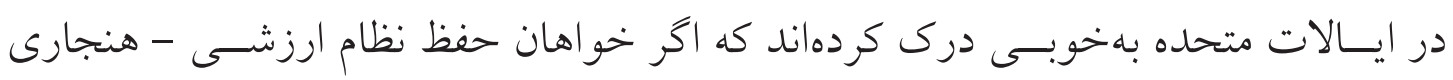

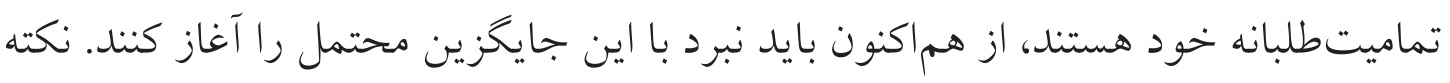
مهم اينجاست كه علىرغم تلاشهاى نظامى نومحافظه كاران طى سالهاى كذشتشنه، كفتمان

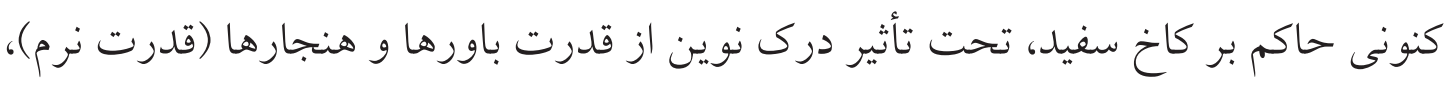

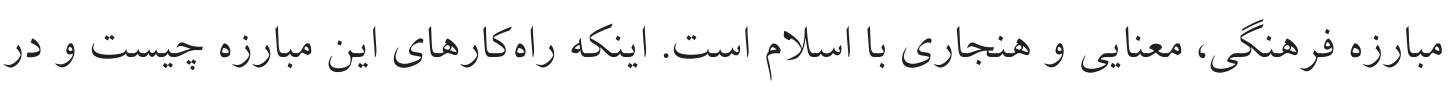

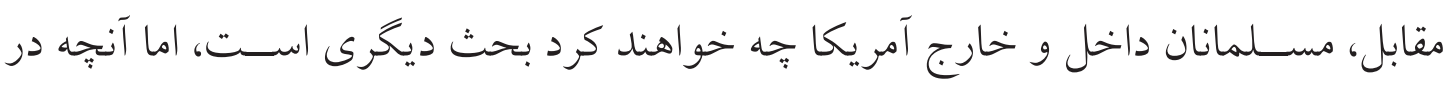

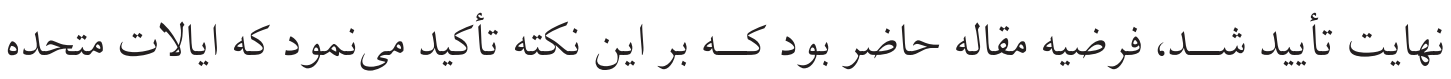

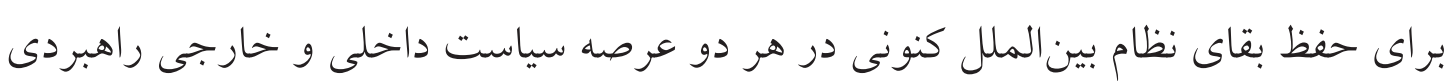

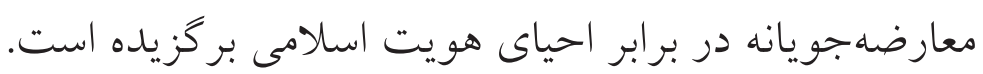




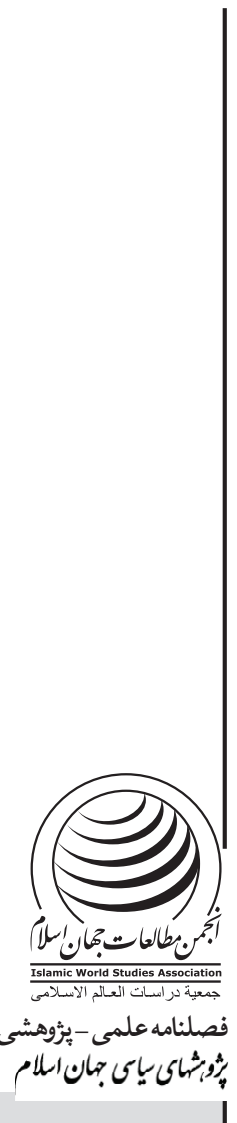

$|f|$

إحياى هويت اسلامى و إنوي

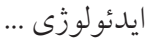

\section{كتابنامه}

آشنايى با گروهها و شخصيت هاى اسلامى در آمريكا (I IVVV). تهر ان: انتشارات صداوسيما.

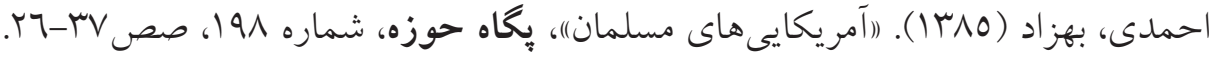

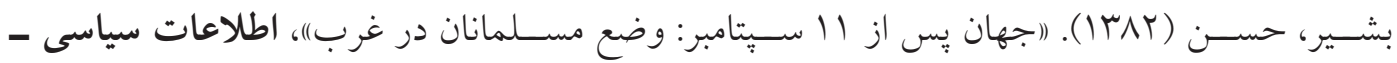

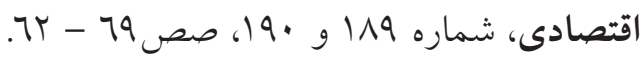

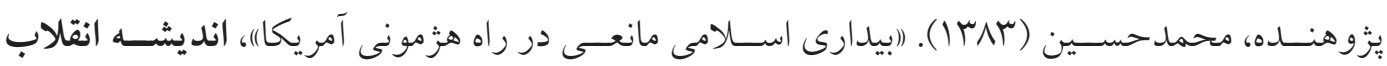

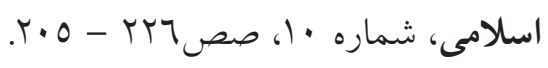

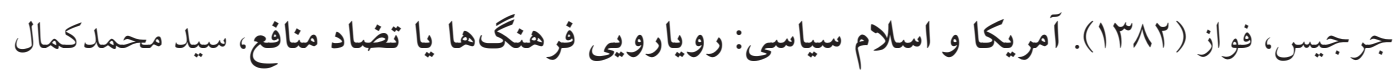
سروريان، تهر ان: انتشارات يزوهشكده مطالعات راهبردى.

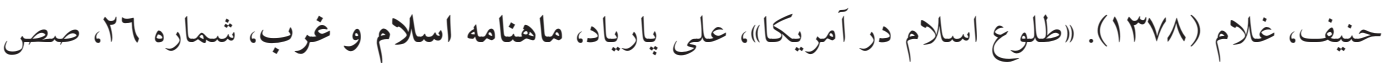
$. r V-r q$

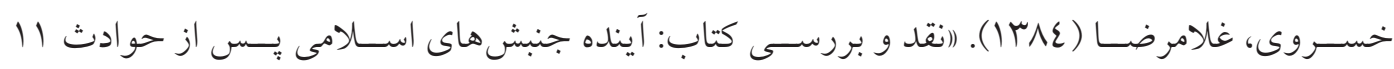

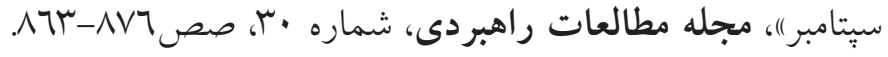

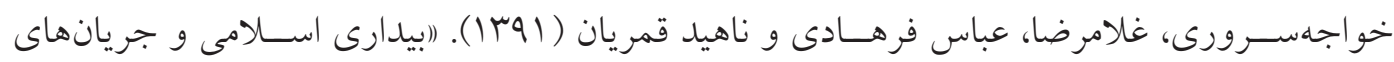

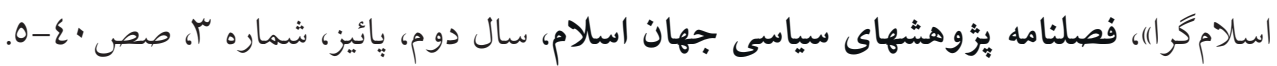

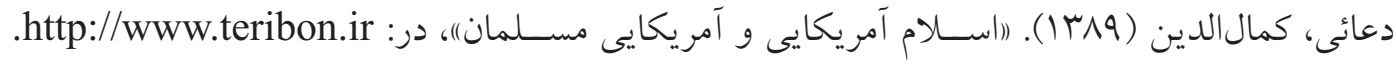

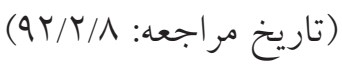
رشيد، عبداله (IrVN) (اساسلام در آمريكا؛ هشت ميليون مسلمان تحت حمايت دار الهجرها)، غلامحسين

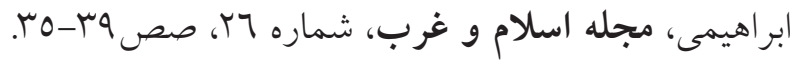

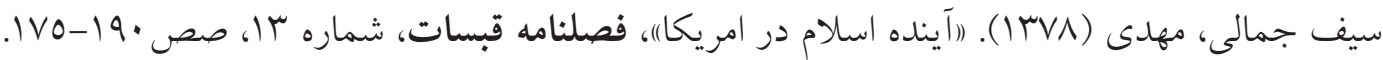

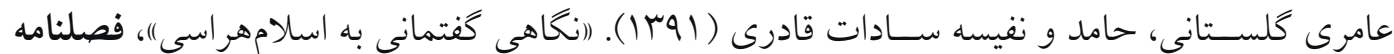

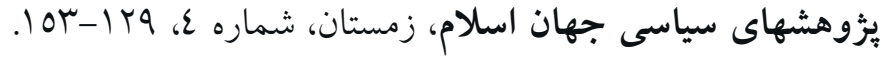

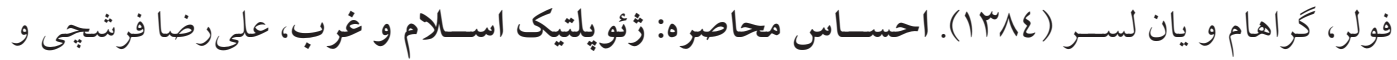

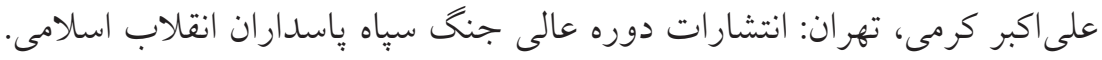

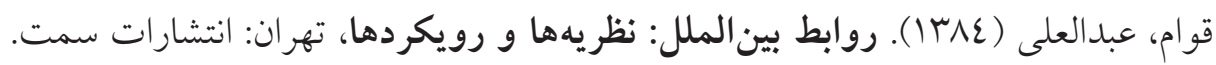

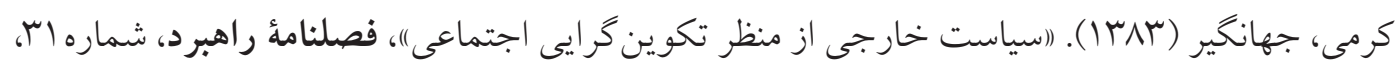
صص 109-1100

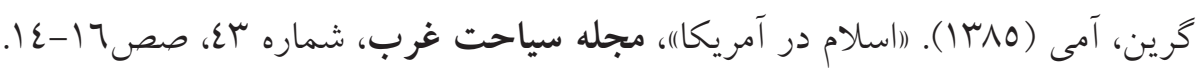

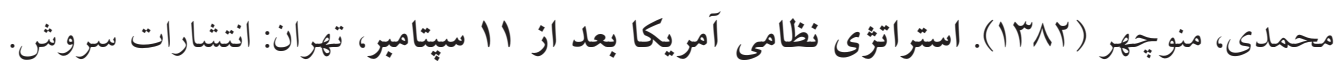

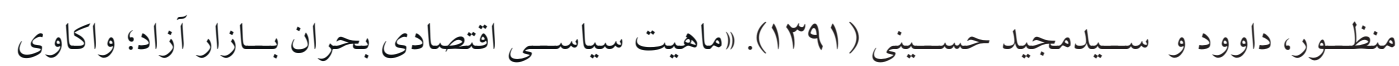
بحرانهاى مالى در نظام ســرمايهدارى با رويكرد اسلامى)، فصلنامه يُوهشهاى سياسى جهان اسلام، سال 
دوم، تابستان، شماره ז، صص •7-Tس.

منصورى، جو اد (برش|). (اسياست راهبردى آمريكا در مقابله با بيدارى اسلامى)، مجله انديشه انقلاب

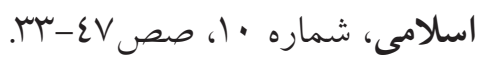

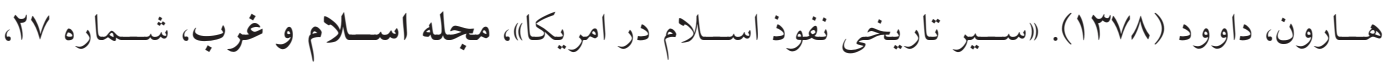

صص •r

Bokhari, Kamran (2002). "A Constructivist Approach to American Foreign Policy”, The American Journal of Islamic Social Sciences, No 3, pp.11-30.

Hopf, Ted (1998). "The Promise of Constructvism in International Relation Theory", International Security, No31, pp. 54-169.

Price, Richard\& Christian Reus-Smit (1998). "Dangerous Liaisons? Critical International Relations Theory and Constructivism", Journal of International Relations, No 4, pp. 259-294.

Vayrynen, Raimo (2002). «Stable Peace through Security Communities? Steps Towards Theory Building», Occasional Paper The Joan B. Kroc Institute for International Peace Studies, at: http://kroc.nd.edu/ocpapers/op_18_3.pdf.

Yazdani, Enayatollah (2008). "Us Policy Towards the Islamic World”, Alternatives: Turkish Journal of International Relations, No 2\&3, pp. 37-46.

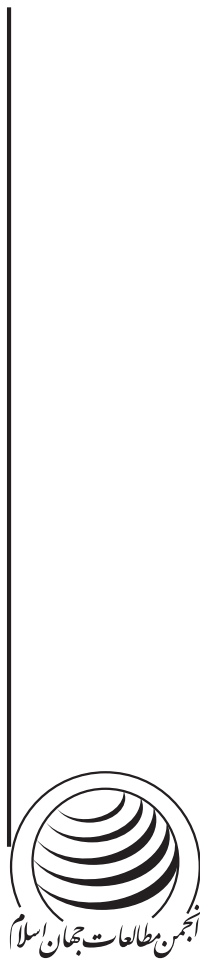

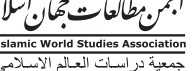

فصلنامه علمى - بثروهشى

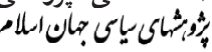

Ifr

سال سوم،

شماره دوم،

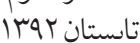

